\title{
Geology and geochemistry of jasperoids from the 'Montaña de Manganeso' district, San Luis Potosí, north-central Mexico
}

\section{Joseph Madondo ${ }^{1}$, Carles Canet ${ }^{2,3, *}$, Fernando Nuñez-Useche ${ }^{4}$, and Eduardo Gonzalez-Partida ${ }^{5}$}

${ }^{1}$ Posgrado en Ciencias de la Tierra, Universidad Nacional Autónoma de México, Ciudad Universitaria, 04510, Mexico City, Mexico.

${ }^{2}$ Instituto de Ciencias de la Atmósfera y Cambio Climático, Universidad Nacional Autónoma de México, Ciudad Universitaria, 04510, Mexico City, Mexico.

${ }^{3}$ Instituto de Geofísica, Universidad Nacional Autónoma de México, Ciudad Universitaria, 04510, Mexico City, Mexico.

${ }^{4}$ Instituto de Geología, Universidad Nacional Autónoma de México, Ciudad Universitaria, 04510, Mexico City, Mexico.

${ }^{5}$ Centro de Geociencias, Universidad Nacional Autónoma de México, Juriquilla, Querétaro, 76230, Mexico.

*ccanet@atmosfera.unam.mx

\section{ABSTRACT}

Large outcrops of jasperoids occur in the 'Montaña de Manganeso' mining district in north-central Mexico. They range from massive manganiferous jasperoids to highly brecciated, hematitic jasperoid. The jasperoids of 'Montaña de Manganeso' occur mainly as replacements of limestone, sandstone and shale, commonly nearby high-angle fault systems. The mineralogy of the jasperoids consist of quartz and its polymorphs (chalcedony, tridymite and cristobalite), Fe-Mn oxyhydroxides, calcite and minor barite. Many outcrops show evidence of several periods of brecciation and silicification. The geochemical signature of the jasperoids suggests that silicification was product of hydrothermal activity. The jasperoids display enrichment in elements of hydrothermal provenance such as $\mathrm{Ba}, \mathrm{Sr}, \mathrm{As}, \mathrm{Cr}, \mathrm{Mo}, \mathrm{Sb}, \mathrm{Ni}, \mathrm{Zn}$ and $\mathrm{Cu}$, whereas are strongly depleted in the elements indicative of clastic sources such as $\mathrm{Ti}, \mathrm{K}$, Th and $\mathrm{Zr}$. Element ratios such as $(\mathrm{Fe}+\mathrm{Mn}) / \mathrm{Ti}$, $\mathrm{Al} /(\mathrm{Al}+\mathrm{Fe}+\mathrm{Mn}), \mathrm{Fe} / \mathrm{Mn}$ and $\mathrm{U} / \mathrm{Th}$, along with the $\mathrm{Al}-\mathrm{Fe}-\mathrm{Mn}$ and $\mathrm{Fe}-$ $\mathrm{Mn}-(\mathrm{Ni}+\mathrm{Co}+\mathrm{Cu}) \times 10$ ternary diagrams confirm a hydrothermal origin. Low $\Sigma$ REE, an enrichment of LREE over HREE, negative Ce anomalies and positive $\mathrm{Y}$ anomalies ( $\mathrm{Y}_{\mathrm{PASS}} / \mathrm{Ho}_{\mathrm{PAAS}}$ ) also support the hydrothermal processes. The geological evidence, in the form of a feeder zone and extensive hydrothermal alteration, show that the silica forming the rocks originated from ascending hot fluids.

Key words: jasperoid; hydrothermal; silicification; Fe-Mn oxides; San Luis Potosí.

\section{RESUMEN}

En el distrito minero de la Montaña de Manganeso en el centro-norte de México se encuentran grandes afloramientos de jasperoides que van desde jasperoides manganíferos masivos hasta jasperoides hematíticos muy brechados. Los jasperoides de la Montaña de Manganeso ocurren principalmente como reemplazamientos de calizas, areniscas y pizarras, comúnmente cerca de sistemas de fallas de alto ángulo. La mineralogía de los jasperoides consiste en cuarzo y sus polimorfos (calcedonia, tridimita y cristobalita), oxihidróxidos de Fe-Mn, calcita y en menor grado barita. Muchos afloramientos muestran evidencia de varios episodios de brechamiento y silicificación. La firma geoquímica de los jasperoides sugiere que la silicificación fue producto de la actividad hidrotermal. Los jasperoides muestran enriquecimiento en elementos de procedencia hidrotermal como $\mathrm{Ba}, \mathrm{Sr}, \mathrm{As}, \mathrm{Cr}, \mathrm{Mo}, \mathrm{Sb}, \mathrm{Ni}, \mathrm{Zn}$ y $\mathrm{Cu}$, mientras que están fuertemente empobrecidos en los elementos indicativos de fuentes clásticas como Ti, $K$, Th y Zr. Relaciones de elementos como (Fe+Mn)/ $\mathrm{Ti}, \mathrm{Al} /(\mathrm{Al}+\mathrm{Fe}+\mathrm{Mn}), \mathrm{Fe} / \mathrm{Mn}$ y $\mathrm{U} / \mathrm{Th}$, junto con los diagramas ternarios $\mathrm{Al}-\mathrm{Fe}-\mathrm{Mn}$ y $\mathrm{Fe}-\mathrm{Mn}-(\mathrm{Ni}+\mathrm{Co}+\mathrm{Cu}) \times 10$ confirman un origen hidrotermal. Un bajo $\Sigma R E E$, un enriquecimiento de LREE sobre HREE, anomalías negativas de Ce y positivas de $Y\left(Y_{\text {PASS }} /\right.$ Ho $\left._{\text {PAAS }}\right)$ también apoyan un origen hidrotermal. La evidencia geológica, en forma de una 'zona de alimentación' y alteración hidrotermal extensa, muestra que la sílice que forma las rocas se originó a partir de fluidos calientes ascendentes.

Palabras clave: jasperoide; hidrotermal; silicificación; óxidos de Fe-Mn; San Luis Potosí.

\section{INTRODUCTION}

Jasperoid is a rock composed mainly of quartz and/or other silica polymorphs, formed by epigenetic hydrothermal replacement of a previously lithified rock (Lovering, 1962, 1972; Fournier, 1985; Theodore and Jones, 1992; Hofstra and Cline, 2000; Yigit et al., 2006). They are documented in several countries including the United States, Mexico, Peru, Australia and China, where they form topographically prominent outcrops because of their resistance to weathering (Bailey, 1974; Murphy, 1995; Arehart, 1996). Lovering (1972) investigated several jasperoid provinces and districts in the USA and Mexico recognizing a genetic and spatial association between jasperoid and ore deposits. 
Jasperoid formation is commonly attributed to hydrothermal activity because of a general spatial relationship between jasperoids and igneous rocks (Lovering, 1972; O'Neil and Bailey, 1979; Wilson et al., 1987; Nelson, 1990; Theodore and Jones, 1992; Murphy, 1995; Johnston et al., 2008; Kirwin and Royle, 2019; Huff et al., 2020). Consequently, most jasperoids are localized along faults, fractures, and shear zones that could serve as channel ways for ascending silica-rich hydrothermal fluids (McKay and Finlow-Bates, 1977; Wilson et al., 1987; Kuehn and Rose, 1992; Yigit et al., 2006). Some jasperoids, however, form lenticular and layered bodies that may resemble bedded chert (Lovering, 1972). Such jasperoids may be difficult to distinguish from bedded cherts, unless the feeder channels can be identified (Lovering, 1972; Wilson et al., 1987; Nelson, 1990).

Jasperoid deposits, as hydrothermal products, can be expected to exhibit the geochemical signature of the fluids from which they precipitated (Renault et al., 1995). Moreover, as jasperoids generally contain substantial amounts of $\mathrm{Fe}$ and Mn oxides with strong adsorption capacity for cations, they even more strongly acquire the geochemical signatures of the mineralizing fluid (Bau et al., 1996; Conly et al., 2011; Sinisi et al., 2012; Papavassiliou et al., 2017). Also, as they are very resistant to chemical weathering and are barely affected by diagenetic changes, their chemistry is suitable for interpreting depositional processes and environment of formation of associated ore deposits (Murray, 1994; Dasgupta et al., 1999). For this reason, jasperoids and their geochemistry have long been applied to mineral exploration, in particular, gold exploration (Lovering and Heyl, 1974; O'Neil and Bailey, 1979; Holland et al., 1988; Nelson, 1990; Graney et al., 1991; Theodore and Jones, 1992; Kirwin and Royle, 2019; Huff et al., 2020).

Massive siliceous bodies crop out prominently in the Central Plateau region of Mexico (Labarthe-Hernandez et al., 1992). These bodies occur as fault-controlled veins and irregular bodies that cut rocks of known continental origin, making it unlikely that they are submarine exhalative Fe-Mn cherts (Crerar et al., 1982; Adachi et al., 1986). Hence, in agreement with previous studies involving these bodies (Albinson, 1988; Labarthe-Hernández et al., 1992), the term jasperoid is preferred here for the Central Plateau siliceous bodies to avoid connotation of diagenetic or exhalative origin usually associated with the term chert (Adachi et al., 1986; Murray, 1994; Murphy, 1995; Binns, 2007).

The common association of jasperoids with precious and basemetal enrichment has focused attention on these metals and not on their generally sub-economic iron and manganese content (Hesse, 1990). This investigation instead takes advantage of the high abundances of manganese and iron oxides in the jasperoids of the Central Plateau region to characterize and understand jasperoid formation through the Fe-Mn oxide geochemistry. The problem of differentiating hydrothermal silica from other types such as biogenic and sedimentary silica is dealt with by demonstrating through field and geochemical characteristics of the jasperoids, the hydrothermal origin of both the silica and the Fe-Mn oxides. The results of this research provide a new approach to understand the metallogenesis of the Central Plateau.

\section{REGIONAL GEOLOGY}

The study area is located in central Mexico on an elevated plateau (average altitude: $\sim 2000 \mathrm{~m}$ a.s.l.) known as the Mesa Central or Central Plateau (Figure 1) (Nieto-Samaniego et al., 2005, 2019). The geology of the study region is characterized by the accretion of the Guerrero terrane over continental Mexico represented by the Sierra Madre terrane (Centeno-García and Silva-Romo, 1997; Centeno-García et al., 2003; Martini et al., 2013). Jurassic ocean floor and island arc volcanosedimentary rocks geologically circumscribed to the Guerrero terrane accreted over the Sierra Madre terrane marine carbonate successions during the Late Cretaceous Laramide orogenesis (Centeno-García and Silva-Romo, 1997; Centeno-García et al., 2003; Martini et al., 2013). In the region, isolated outcrops of intraoceanic arc andesitic and pillow lavas, cherty pelagic limestones and radiolarite-chert blocks

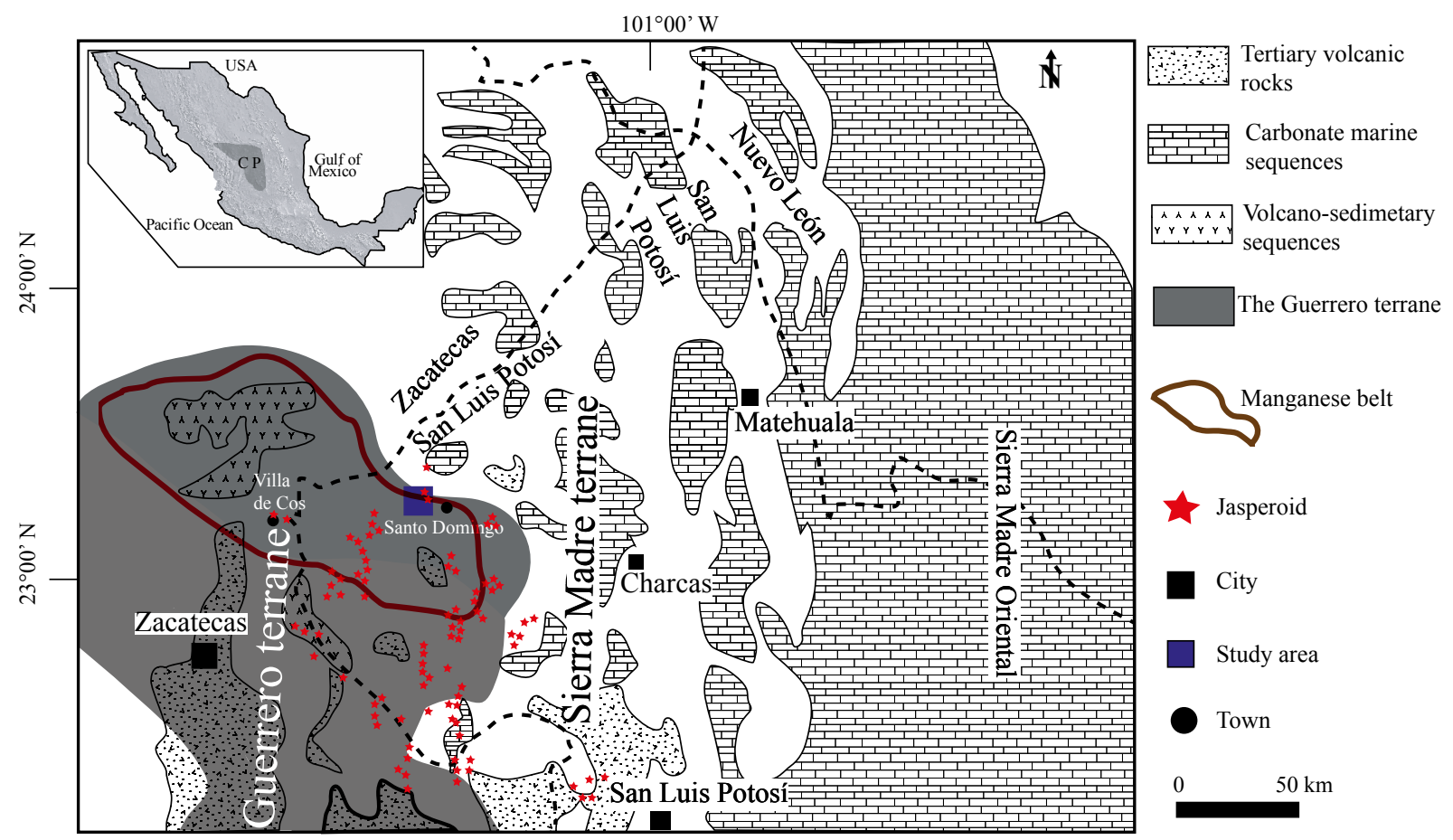

Figure 1. Geologic map of the region (modified after Hope et al., 2002) showing the distribution of some jasperoid bodies (after Sanchez-Rojas, 2013). The boundary of the Guerrero terrane reflects the limit recommended by SGM $(2016,2018)$. 
characterize the Guerrero terrane (Centeno-García and Silva-Romo, 1997) (Figure 2).

Marine Mesozoic successions of late Triassic to late Cretaceous age constitute the Sierra Madre terrane (Carrillo-Bravo, 1982; JuárezArriaga et al., 2019). The basement rocks, which correspond to Upper Triassic-middle Jurassic turbidites (Centeno-García and Silva-Romo, 1997; Barboza-Gudiño et al., 1998, 2010), are overlain by Lower to Middle Jurassic continental arc deposits (Barboza-Gudiño et al., 1999, 2008). Upper Jurassic to Late Cretaceous shallow marine carbonate sequences and clastic sediments cover the continental arc deposits (Carrillo-Bravo, 1982).

The Guerrero terrane accretion to continental Mexico in the Late Cretaceous, caused by the subduction of the Farallon plate beneath the North American plate, produced regional thrust faults (Figure 2). These faults were partly reactivated as normal faults during the subsequent development of the Paleogene Basin and Range extensional tectonics (Tristán-González et al., 2009b). The transition from compressional tectonics of the Guerrero terrane accretion to extensional tectonics of the Basin and Range was marked by the onset of the continental volcanism of the Sierra Madre Occidental (Ferrari et al., 2002; AguirreDíaz et al., 2008). During the Oligocene, the ignimbrite flare-up event resulted in the large-volume ignimbrites which make the Sierra Madre Occidental one of the largest silicic igneous province on earth (McDowell and Clabaugh, 1979; Ferrari et al., 2002, 2007; Aguirre-Díaz et al., 2008; Aguirre-Díaz and Labarthe-Hernández, 2003).

The partial overlap of this silicic magmatic event and the Basin and Range extension generated multiple and discrete episodes of fissural rhyolitic volcanism mostly controlled by major NW-SE trending fault systems (Tristán-González, 1986; Aguirre-Díaz and LabartheHernández, 2003; Aguirre-Díaz et al., 2008; Tristán-González et al., 2008, 2009b; Aguillón-Robles et al., 2012, 2014; Zamora-Vega et al., 2018). The silicic nature of the volcanism also ensured the supply of vast amounts of silica, which generated extensive areas of jasperoid occur- rences in the Central Plateau (Labarthe-Hernández et al., 1992). The Sierra Madre Occidental magmatism triggered a period of intense hydrothermal activity in the Central Plateau that generated different types of mineral deposits (Aranda-Gómez and Mcdowell, 1998; ArandaGómez et al., 2007; Nieto-Samaniego et al., 2007; Tristán-González et al., 2008, 2009b; Rodríguez-Ríos et al., 2013). In the Zacatecas state, west of the study area, this hydrothermal activity is associated with precious metal and polymetallic epithermal deposits (Ponce and Clark, 1988; Henry and Aranda-Gomez, 1992; Nieto-Samaniego et al., 1996, 2007; Aguirre-Díaz et al., 2008; Aguillón-Robles et al., 2009; Zamora-Vega et al., 2018).

\section{METHODOLOGY}

Eleven highly silicified samples, collected from different outcrops, were analyzed for this study. Most of these are jasperoids, but three of the samples show contents of silica $(<10.1 \%)$ lower than those of jasperoids (Lovering, 1972) due to high contents of $\mathrm{MnO}_{2}$, and in fact represent manganese ore. However, for convenience, the general term jasperoid is used here for all the samples analyzed.

Textural characterization of the Fe-Mn oxides was first carried out visually in hand specimens and in thin sections. For a more detailed textural and mineral identification, petrography and scanning electron microscopy (SEM) were carried out on six polished sections at the Central Analytical Facility of the Faculty of Science of the University of Johannesburg, South Africa. Energy dispersive spectrometry (EDS) was used for semi-quantitative determination of concentration of elements in certain minerals. Microscopic images were taken on carbon-coated polished sections using backscattered electrons (BSE) on a Vega 3 Tescan system equipped with an Oxford X-Max $50 \mathrm{~mm}^{2}$ energy dispersive spectrometer (EDS). The software used was an Oxford Aztec software V. 2.2.

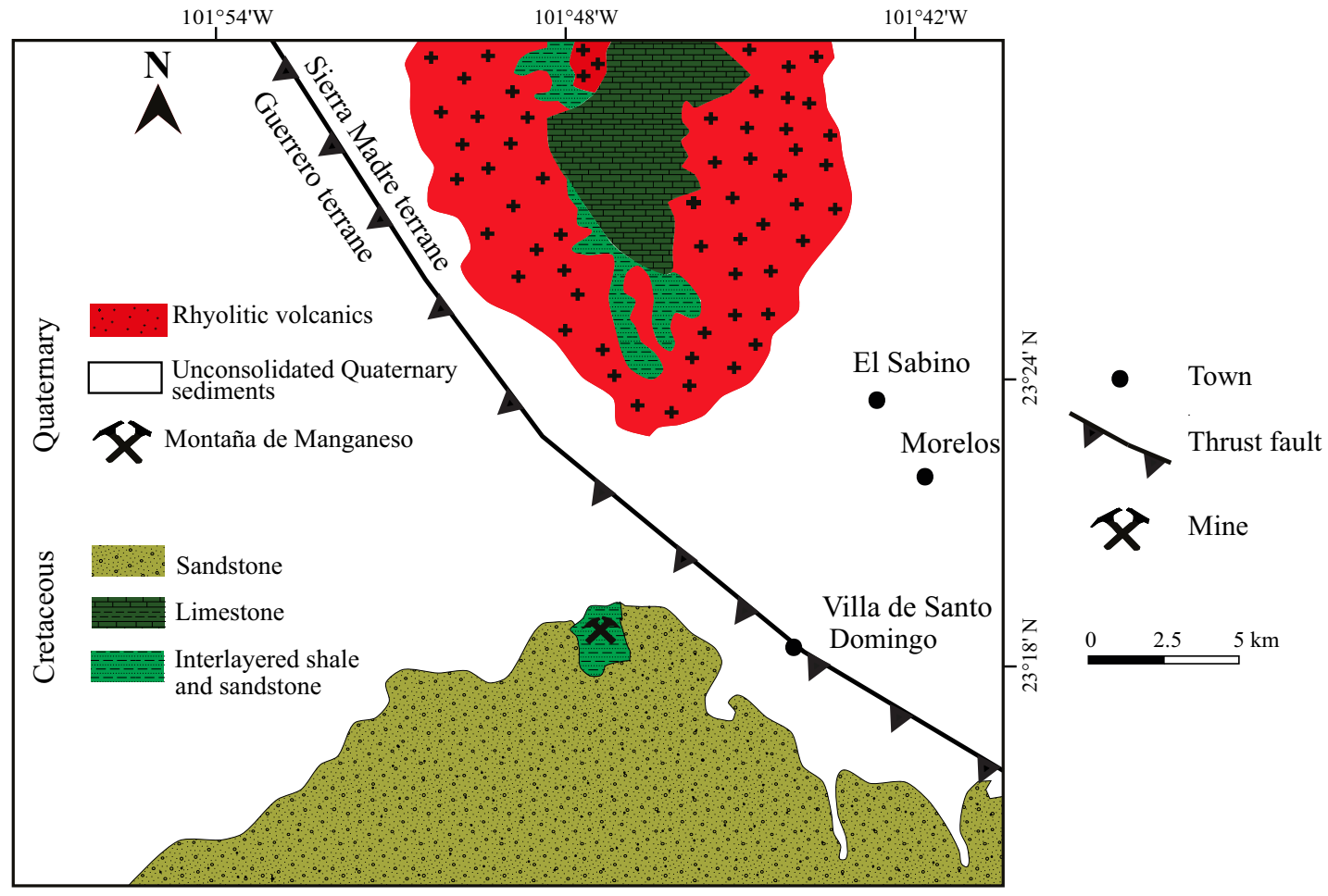

Figure 2. Generalized geologic map of the study area (modified after SGM, 2001). 
Bulk mineralogy of 10 samples was determined by powder X-ray diffraction (XRD) using an Empyrean diffractometer equipped with $\mathrm{Ni}$ filter, a Cu tube of fine focus and a PIXcel ${ }^{3 \mathrm{~d}}$ detector, at the Instituto de Geología, Universidad Nacional Autónoma de México (UNAM). Measurements were performed in the $2 \theta$ angular range from $5^{\circ}$ to $70^{\circ}$, in step scanning with a step scan of $0.003^{\circ}(2 \theta)$ and an integration time of 40 s per step. Rock samples were previously crushed and milled to 200 mesh and homogenized. Data were interpreted using HighScore Plus v4 software (PANalytical). Conventional search and match techniques were employed for qualitative analysis.

Major and trace elements (including REE) concentrations were determined for nine samples at Activation Laboratories (ActLabs, Canada) using the Lithogeochemistry analytical package '4Litho'. This method is a combination of lithium metaborate/tetraborate fusion ICP whole rock for major elements and ICP-MS for major elements and REE (for details see http://www.actlabs.com). Calibration was performed using prepared USGS- and CANMET-certified reference materials. A correlation matrix of elemental concentrations was prepared using the software Statistica version 13. Binary and ternary discrimination diagrams were processed with the GCDkit package for R version 3.6.0.

To evaluate the influence of hydrothermal activity, the $\mathrm{Fe} / \mathrm{Mn}$ (Hein et al., 1997), (Fe+Mn)/Ti (Jun et al., 2010$)$ and $\mathrm{Al} /(\mathrm{Al}+\mathrm{Fe}+\mathrm{Mn}$ ) ratios were calculated (Adachi et al., 1986). To determine the source of $\mathrm{Fe}$ and $\mathrm{Mn}$ in the jasperoids $\mathrm{Ce}$ and $\mathrm{Eu}$ anomalies $\left(\mathrm{Ce} / \mathrm{Ce}^{\star}\right.$ and $\mathrm{Eu} / \mathrm{Eu}^{\star}$ ) were calculated using the equations proposed by Taylor and McLennan (1985):

$$
\begin{aligned}
\mathrm{Ce} / \mathrm{Ce}^{*} & =(\mathrm{Ce}) \mathrm{CN} / \sqrt{[(\mathrm{La}) \mathrm{CN} \times(\mathrm{Pr}) \mathrm{CN}]} \\
\mathrm{Eu} / \mathrm{Eu}^{*} & =(\mathrm{Eu}) \mathrm{CN} / \sqrt{[(\mathrm{Sm}) \mathrm{CN} \times(\mathrm{Gd}) \mathrm{CN}]}
\end{aligned}
$$

wherein these expressions, Eu and $\mathrm{Ce}$ are the actual concentrations and $\mathrm{Eu}^{*}$ and $\mathrm{Ce}^{\star}$ are the predicted concentrations based on interpolation of neighboring REE, using chondrite-normalized abundances (Boynton, 1984). The $\mathrm{Y}$ anomaly, also used to determine the source of Fe and $\mathrm{Mn}$, was calculated using the equation ( $\mathrm{Y}_{\mathrm{PAAS}} / \mathrm{Ho}_{\mathrm{PAAS}}$ ) (Bau et al., 2014). The subscript "CN" and "PAAS" indicate chondrite-normalized (Boynton, 1984) and Post Archean Australian Shale normalized values, respectively. The heavy-REE (HREE), middle-REE (MREE) and lightREE (LREE) are defined as the elements from $\mathrm{La}$ to $\mathrm{Nd}, \mathrm{Sm}$ to $\mathrm{Tb}$ and Dy to $\mathrm{Lu}$, respectively.

\section{GENERAL CHARACTERISTICS OF MEXICAN JASPEROIDS}

Several protruding jasperoid outcrops (Figure 1) are documented in the Mexican Central Plateau (Labarthe-Hernández et al., 1992). The jasperoids generally occur as flared-up, funnel shaped veins of widely variable dimensions. Tabular bodies with thicknesses ranging from 2 to $20 \mathrm{~m}$ (and rare bodies of up to $50 \mathrm{~m}$ ) occur occasionally, extending up to $2 \mathrm{~km}$ in length (Labarthe-Hernández et al., 1992). Most jasperoid bodies are black or red, although yellow, green, and brown colored jasperoids often occur. Outcrops range from hard, massive jasperoids to highly brecciated jasperoids re-cemented by younger quartz. Textures vary from aphanitic to coarse crystalline varieties. Late quartz, calcite and barite form crosscutting veinlets or fill vugs and open spaces (Labarthe-Hernández and Aguillón-Robles, 1986). Iron and manganese oxides dominate the non-silica components of the jasperoids.

Most jasperoid bodies trend NW-SE (with subordinate NE-SW and E-W directions) and are fracture controlled (Labarthe-Hernández et al., 1992). The NW-SE trending direction fairly coincides with that of the regional San Luis-Tepehuanes-fault system, whose main activity occurred during the early Oligocene, with multiple reactivations in the late Oligocene and Miocene (Nieto-Samaniego et al., 2007). This fault system controlled the distribution of several mineral deposits in the Central Plateau (Camprubí and Albinson, 2007; Nieto-Samaniego et al., 2007). The manganiferous jasperoids are more widespread in the regions close to the boundary of the Guerrero terrane and the Sierra Madre terrane, where they constitute a metallogenetic belt (LabartheHernández et al., 1992; Sánchez-Rojas, 2013). Trask and RodríguezCabo (1948) reported at least 20 manganiferous jasperoids in this region, with exploitation of the manganese content occurring at Montaña de Manganeso (MdM) and the La Abundancia districts ( $\sim 60 \mathrm{~km} \mathrm{~W}$ of $\mathrm{MdM})$. A similar close spatial relationship exists between jasperoids and base metal deposits at Real de Ángeles and Villa de Ramos ( 55 and $100 \mathrm{~km}$ SSE of MdM, respectively) (Labarthe-Hernández et al., 1992).

The jasperoids of the Central Plateau replace Cretaceous marine carbonate rocks of the Sierra Madre terrane, but occasionally replace volcano-sedimentary rocks of the Guerrero terrane and Oligocene continental igneous rocks (Labarthe-Hernández et al., 1982, 1992). Silicification is typically pervasive, obliterating the original characteristics of the rocks. However, in some jasperoids the replacement is partial, preserving the original host rock textures. An argillic alteration often exists laterally to the jasperoids suggesting formation from near neutral pH, low temperature hydrothermal solutions (cf. Reyes, 1990; Sánchez-Córdova et al., 2019; Fulignati, 2020). According to LabartheHernández and Aguillón-Robles (1986), the jasperoids formed from replacement of host rocks by multiple silica generations injected from ascending hot fluids during the waning stage of hydrothermal activity associated with mostly unidentified intrusions.

The age of the Central Plateau jasperoids is not well constrained. The available ages, based on stratigraphic correlation of replaced rocks and the age of the associated intrusives, are not consistent, varying from <30 Ma to >32.7 Ma (K/Ar) (Labarthe-Hernández et al., 1992). Based on intimate spatial association to intrusive rocks of Tertiary age, Labarthe-Hernández et al. (1992) assumed the majority of jasperoids to be Oligocene. This age is consistent with the 30 to $35 \mathrm{Ma}(\mathrm{K} / \mathrm{Ar})$ range estimated for the La Colorada, Fresnillo and Sombrerete jasperoids (Albinson, 1988).

\section{The Montaña de Manganeso jasperoids}

Jasperoids from the MdM occur primarily as fault-controlled blocky bodies of variable size (Figure 3a, 3b), mostly confined to NEtrending faults within strongly folded and fractured volcaniclastic rocks (Trask and Rodríguez-Cabo, 1948; Wilson and Rocha, 1948; Alexandri, 1976). The epigenetic nature of the jasperoids is unambiguous, exhibiting a cross-cutting relationship with their host rocks. The jasperoids generally strike $\mathrm{N} 25^{\circ} \mathrm{E}$ with a dip of $70^{\circ}$ to $80^{\circ} \mathrm{NW}$ (Wilson and Rocha, 1948). Occasionally they present transitional contacts that grade into partly silicified limestone, sandstone and shale. They are closely associated with manganese ores, and occasionally present mutual cutting relationships and gradational contacts.

In MdM red and black jasperoids usually occur spatially separated (Figure 3a, 3b). However, occasionally the hematitic (red) jasperoids gradually change into the manganiferous (black) jasperoids, which in turn transition into $\mathrm{Mn}$ ore with an associated increase in Mn content (Figure 4).

The differences in color reflect varying proportions of non-silica minerals, particularly the iron and manganese oxide content (Figure $3 c, 3 e, 3 f)$. The red jasperoids are rich in iron oxides, mainly hematite, which imparts them a distinctive intense red tint (Figure 5a-5d). Minor yellowish brown (goethitic) and rare green (pyritiferous) varieties also occur among the Fe rich jasperoids (Figure 5e-5g). Some jasperoids are mineralogically heterogeneous, with $\mathrm{cm}$ to $\mathrm{mm}$ scale variations in color visible at outcrop and thin section scale (Figure 3d). Bleaching of 

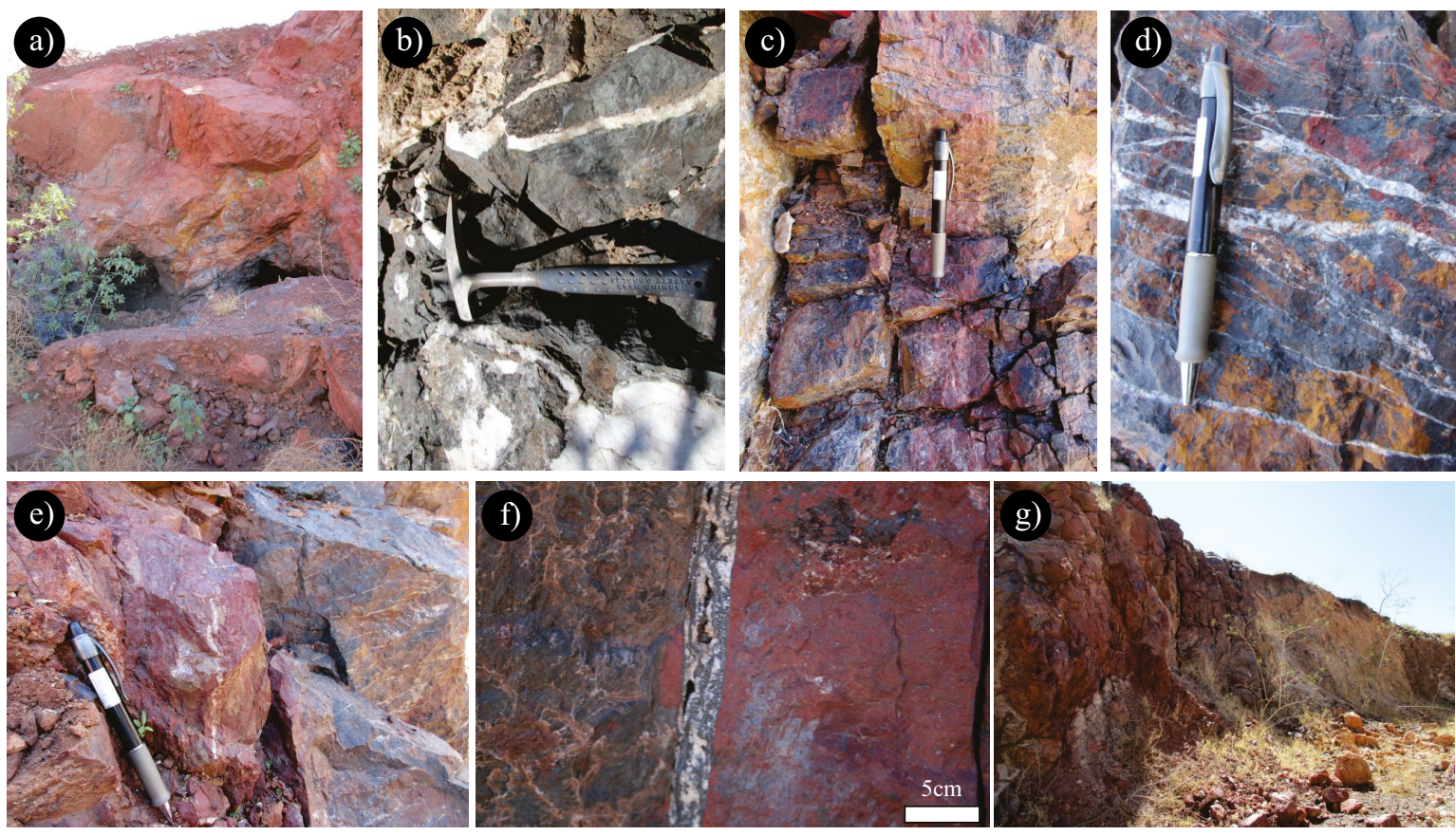

Figure 3. Representative outcrop photos of jasperoids from the Montaña de Manganeso: (a) Blocky hematitic jasperoids. (b) Manganiferous jasperoids with calcite veins. (c-f) Veined and mineralogically heterogeneous jasperoids, with $\mathrm{mm}$ to $\mathrm{cm}$ scale variations in color visible at outcrop scale; a complete separation of Mn and Fe in the jasperoids is commonly observed. (g) Exposed part of the feeder zone with silicified Fe-Mn oxides lining the fractures.

the hematitic jasperoids produced a characteristic pseudo-brecciated texture characterized by hematite-rich zones surrounded by a white microcrystalline matrix (Figure $5 \mathrm{~h}$ ). The manganiferous jasperoids are less heterogenous, exhibiting various shades of gray (Figure 5i-5l) depending on the Mn oxide concentrations.

The MdM jasperoids display a variety of macroscopic textures such as massive (Figures 3a,3b, 5e), brecciated (Figure 5a-5c) and laminated (Figure 6a, 6b). These textures are a result of multiple episodes of replacement, brecciation, and veining through episodic injection of silica by the hydrothermal system. Massive jasperoids are relatively common and have a dense aphanitic texture that reflects uniform distribution of either manganese oxides (Figure 7c) or hematite grains (Figure 7d, 7h) within the silica matrix. The laminated jasperoids consist of fine grained visually distinctive hematite-rich laminae variably modified or obliterated by veining and brecciation (Figures $6 c-6 f, 7 a, 7 b$ ). Veining is manifested as a network of quartz veinlets that replace older generations of quartz and Fe-Mn oxides (Figure 8f, 8g). Brecciation is characteristic of samples from the feeder zone (Figure $3 \mathrm{~g}$ ).

The jasperoids also exhibit several ductile (Figure 6a, 6b) and brittle (Figure 6d, 6f) deformation structures. Diagenetic dehydration (Figure $6 c, 6 e)$ produced fractures expressed as a pseudobreccia texture in some jasperoids. These structures are easily identifiable in the red iron-rich jasperoids but are less visible in the black manganese-rich jasperoids because the darker color of the latter has obscured them (Figure 6i-6l).

\section{RESULTS}

\section{Petrography}

Quartz, the main component of the jasperoids at MdM, occurs mainly as anhedral crystals ranging in size from cryptocrystalline to microcrystalline and coarse crystalline $(<2 \mathrm{~mm}$ ) (Figure $8 \mathrm{a}-8 \mathrm{c})$. A greater part of the quartz appears to have recrystallized from chal- cedony (Figure 5k), as in most samples a transition from chalcedony to coarse quartz is observed (Figure $8 \mathrm{~d}, 8 \mathrm{e}$ ). Rare euhedral quartz grains (Figure $8 \mathrm{~h}, 8 \mathrm{i}$ ), probably representing quartz precipitated directly from the hydrothermal fluid, also occur. Late stage quartz appears as mostly anhedral coarse crystalline grains that fill fractures whose walls are lined by a thin layer of microcrystalline quartz (Figures 5j, 8f, 8g).

Manganese and iron oxides are ubiquitous in the jasperoids. They mostly occur as Fe-oxide rich and Mn-oxide rich bands (Figure 7a, 7b). The intense black, red or brown colored jasperoids suggestive of high Fe-Mn oxide contents can actually result from silica sparsely stained with disseminated and fine-grained manganese oxides (Figure 7c),

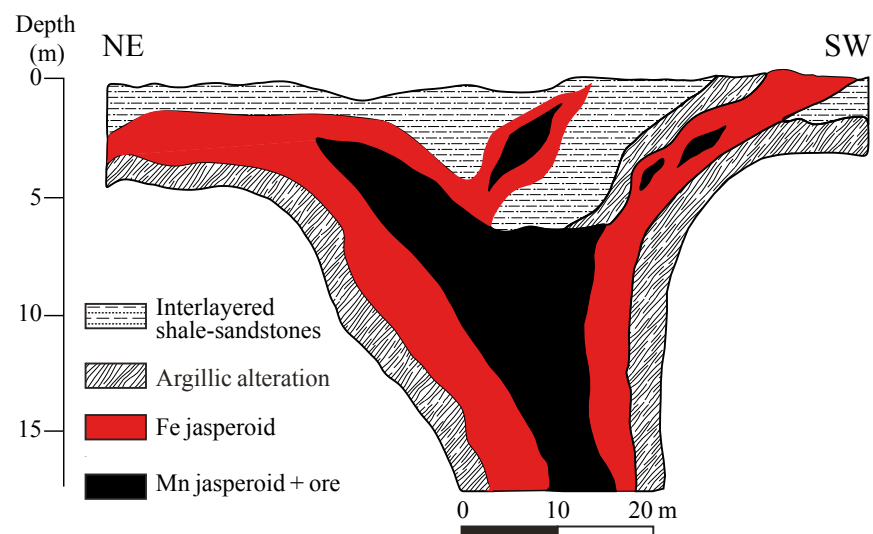

Figure 4. Schematic cross-section of an ore related jasperoid body at Montaña de Manganeso showing major alteration and mineralization features. The ore occur as massive black lenses of manganiferous jasperoid within hematitic jasperoids. The jasperoids have associated zones of argillic alteration that are suggestive of a hydrothermal origin. 

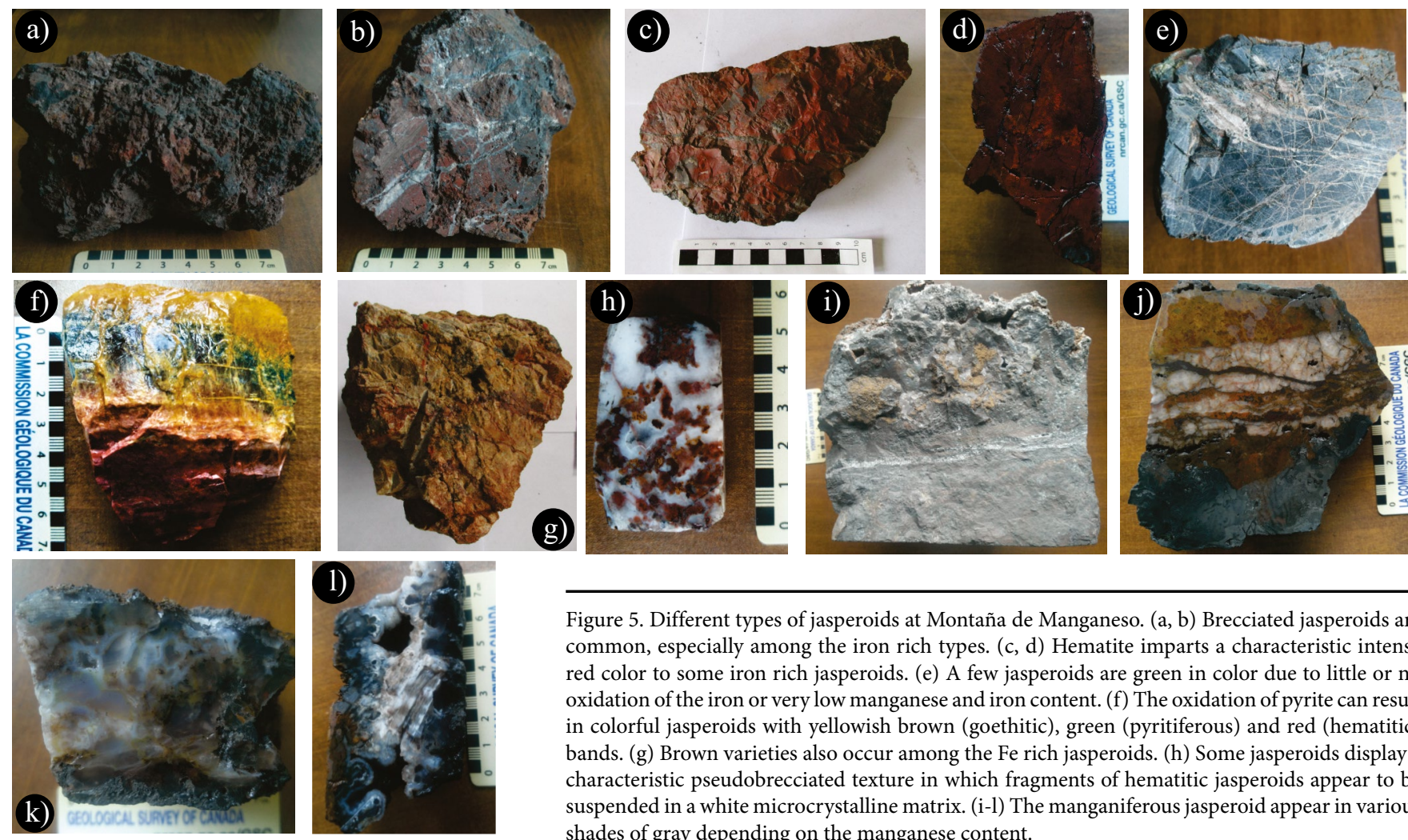

Figure 5. Different types of jasperoids at Montaña de Manganeso. (a, b) Brecciated jasperoids are common, especially among the iron rich types. (c, d) Hematite imparts a characteristic intense red color to some iron rich jasperoids. (e) A few jasperoids are green in color due to little or no oxidation of the iron or very low manganese and iron content. (f) The oxidation of pyrite can result in colorful jasperoids with yellowish brown (goethitic), green (pyritiferous) and red (hematitic) bands. (g) Brown varieties also occur among the Fe rich jasperoids. (h) Some jasperoids display a characteristic pseudobrecciated texture in which fragments of hematitic jasperoids appear to be suspended in a white microcrystalline matrix. (i-l) The manganiferous jasperoid appear in various shades of gray depending on the manganese content.

hematite (Figure 7d) and goethite (Figure 7e), respectively. Hematite also occurs as globular aggregates of smaller microspheroids $(<1 \mu \mathrm{m})$ (Figure 7f, $7 \mathrm{~g}$ ). In samples where hydrothermal replacement has been incomplete radiolarians locally accompany iron and manganese oxides (Figure $7 \mathrm{~h}, 7 \mathrm{i}$ ).

\section{Mineralogy}

Quartz and its polymorphs cristobalite and tridymite make up the major component of the jasperoids (71-98\%). Besides quartz, the samples contain barite, calcite, pyrite, goethite, hematite, magnetite, hollandite, pyrolusite, todorokite and birnessite in varying proportions (Table 1). Except for the abundance of manganese oxides, the mineralogy of the MdM jasperoids is similar to that of other jasperoids (e.g. Lovering, 1972; Wilson et al., 1987; Nelson, 1990; Theodore and Jones, 1992; Yigit et al., 2006).

Iron and Mn oxyhydroxide minerals make the major accessory minerals, a characteristic that has been used to group the samples into Fe-rich (mostly hematitic) and Mn-rich (manganiferous) jasperoids (Table 1). Although the proportions vary, the mineralogy of the hematitic jasperoids is quite simple, with most samples having 80-95\% quartz, $2-16 \%$ hematite and minor amounts of goethite. Hematite and goethite are recognizable in hand specimens (Figure 5). The manganiferous jasperoids are more heterogeneous in terms of their accessory mineral contents. X-ray diffraction identified todorokite, pyrolusite, hollandite and birnessite. Finely disseminated pyrite coexists with hematite, goethite and magnetite in the manganiferous jasperoids.

\section{Whole-rock geochemistry \\ Major elements}

Jasperoids from the MdM deposit are composed predominantly of $\mathrm{Si}, \mathrm{Fe}, \mathrm{Mn}$ and volatile components (LOI) (Table 2). $\mathrm{SiO}_{2}$ concentrations in the jasperoids vary from 65.53 to $91.96 \mathrm{wt}$. $\%$ in the non-ore jasperoid proper. The high values of $\mathrm{SiO}_{2}$ reflect the abundance of quartz and its polymorphs tridymite, cristobalite and chalcedony, as the dominant minerals in the jasperoids.

The $\mathrm{MnO}$ (tot) varies from 0.08 to $12.44 \mathrm{wt} \%$ in the jasperoids proper, and from 57.68 to $59.69 \mathrm{wt} . \%$ in the two ore samples analyzed here. High Mn concentrations are related to the occurrence of $\mathrm{Mn}$ oxides (birnessite, todorokite and hollandite; Table 1). $\mathrm{Fe}_{2} \mathrm{O}_{3}$ (tot) content in the jasperoids varies from 1.31 to $32.09 \mathrm{wt} . \%$, related with the presence of hematite and subordinate goethite, magnetite and pyrite. In the two ore samples $\mathrm{Fe}_{2} \mathrm{O}_{3}$ (tot) concentrations are low, ranging from 1.31 to $2.77 \mathrm{wt}$ \%. The $\mathrm{Al} /(\mathrm{Al}+\mathrm{Fe}+\mathrm{Mn})$ ratio for the $\mathrm{MdM}$ jasperoids varies from 0.01 to 0.05 , with one anomalous value of 0.45 . The ratios $(\mathrm{Fe}+\mathrm{Mn}) / \mathrm{Ti}$ and $\mathrm{Fe} / \mathrm{Mn}$ vary widely, from 76 to 94803 and from 0.02 to 152.95 , respectively.

The remaining major elements $(\mathrm{Ti}, \mathrm{Al}, \mathrm{Mg}, \mathrm{Ca}, \mathrm{Na}, \mathrm{K}$, and $\mathrm{P}$ ) are less than 3 wt.\%. $\mathrm{CaO}(<1.46$ wt.\%) concentrations can be accounted for by the presence of calcite and/or the Ca content in the lattice structure of some manganese oxides such as todorokite and birnessite. The low concentrations of $\mathrm{K}_{2} \mathrm{O}(<0.64 \mathrm{wt} . \%)$ reflect the absence of cryptomelane in the studied samples and possibly also the leaching of $\mathrm{K}$ to form illite, which is widespread as hydrothermal alteration at MdM (Madondo et al., 2020). $\mathrm{Na}_{2} \mathrm{O}(<0.2 \mathrm{wt} . \%)$ concentrations are very low, reflecting the presence of minor amounts of $\mathrm{Na}$ bearing minerals like birnessite and/or smectites (Table 1; Madondo et al., 2020).

Low $\mathrm{TiO}_{2}(<0.035 \mathrm{wt} . \%)$ concentrations indicate limited lithogenic components whereas the moderate $\mathrm{Al}_{2} \mathrm{O}_{3}(<1.9$ wt.\%) concentrations may be reflecting presence of hydrothermal kaolinite that is abundant at $\mathrm{MdM}$ (Madondo et al., 2020). The $\mathrm{Al}_{2} \mathrm{O}_{3}$ concentrations in the $\mathrm{MdM}$ jasperoids may also be representing the detrital aluminosilicate fraction from the replaced host rock, as reflected by the positive correlation between $\mathrm{Al}_{2} \mathrm{O}_{3}$ vs. $\mathrm{TiO}_{2}, \mathrm{MgO}, \mathrm{CaO}$ and $\mathrm{K}_{2} \mathrm{O}(r: 0.66,0.94,0.81$ and 0.72 , respectively; Table 3) (Hein et al., 2000). 

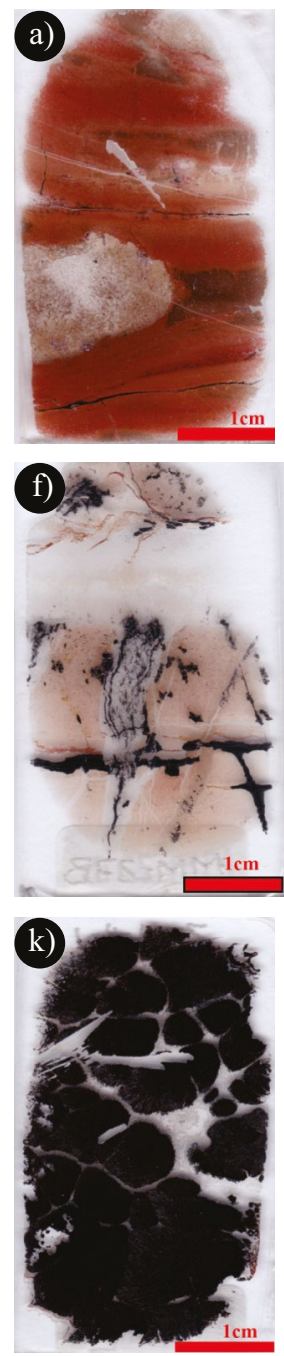
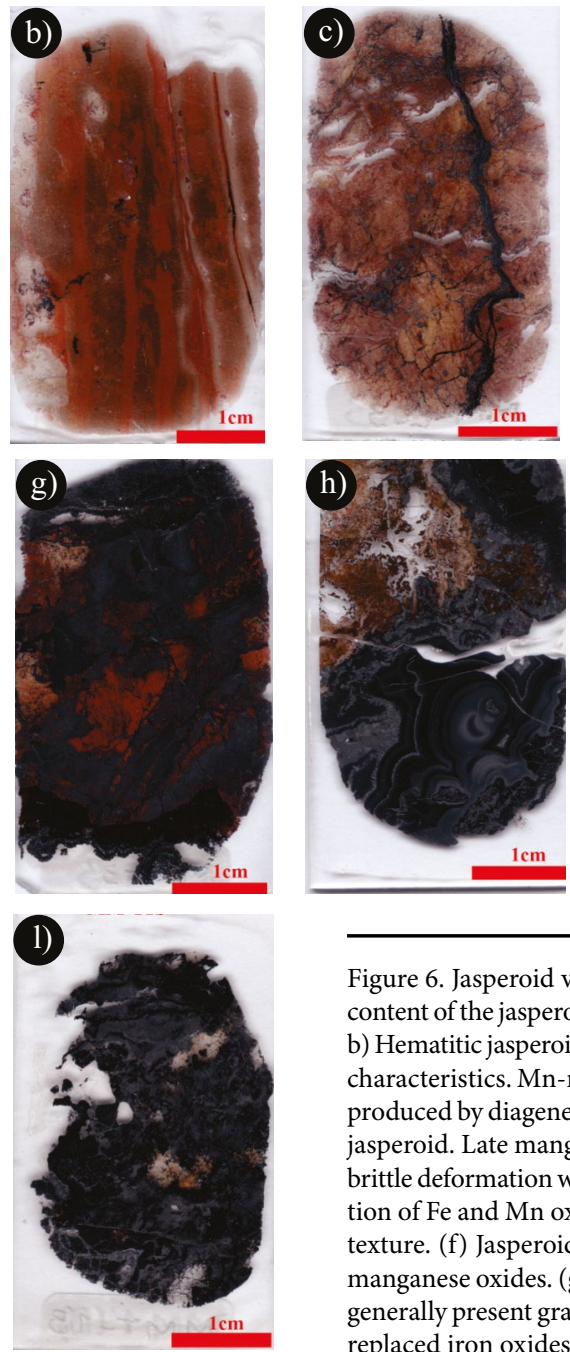
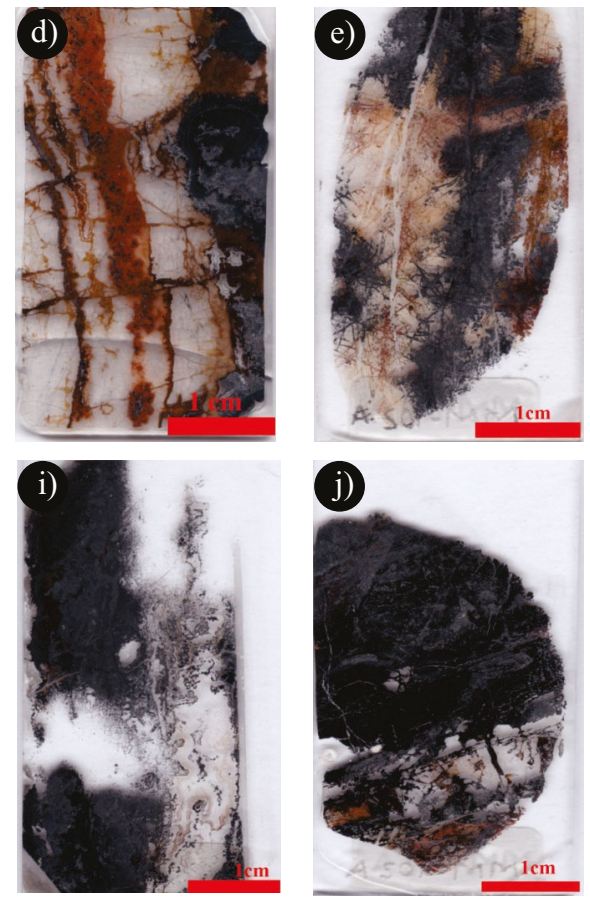

Figure 6. Jasperoid varieties with typical textures observed in thin section scans. The Mn content of the jasperoid generally increases from A to L whereas the Fe content decreases. (a, b) Hematitic jasperoids with well-preserved primary layered texture and ductile deformation characteristics. Mn-rich and Fe-rich laminae can be observed. (c) Jasperoid pseudobreccia produced by diagenetic dehydration. Fine grained hematite is disseminated throughout the jasperoid. Late manganese oxides fill the fractures. (d) Micro faulting of jasperoids due to brittle deformation with fracture filling and replacement Fe and Mn oxides. Note the separation of Fe and Mn oxides. (e) Pervasive microfractures have produced a pseudobrecciated texture. (f) Jasperoid with sparse disseminated fine grained hematite and fracture filling manganese oxides. (g, h) Jasperoids with comparable Fe and Mn contents. Such jasperoids generally present gray to light brown colors. (i-l) Manganese oxides have almost completely replaced iron oxides with only remnants of iron oxides still visible.
The Loss on Ignition (LOI) varies from 0.55 to $13.45 \%$ (Table 2); representing mostly the water content of the jasperoids. However, this water is associated with the content of the Mn oxides in the jasperoids and not with chalcedony, as might be expected. Manganese oxides, particularly birnessite and todorokite frequently contain water in their crystal lattice (e.g. Post, 1999). A near perfect positive correlation exists between $\mathrm{MnO}$ and LOI ( $r=0.98$; Table 3$)$. On the contrary, a marked negative correlation occurs between $\mathrm{SiO}_{2}$ and LOI $(r=-0.96$; Table 3$)$. A possible cause for the negative correlation could be the fact that $\mathrm{SiO}_{2}$ mainly exists as quartz rather than the often water-bearing chalcedony. Furthermore, $\mathrm{MnO}$ and $\mathrm{SiO}_{2}$ show a high negative correlation $(r=-0.98)$, which reflects their co-occurrence as the dominant constituents of the jasperoids. $\mathrm{K}_{2} \mathrm{O}$ show negative correlations with $\mathrm{SiO}_{2}$ and $\mathrm{Fe}_{2} \mathrm{O}_{3}$ (tot) ( $r$ : -0.40 and -0.70 , respectively). These correlations probably reflect the jasperoid replacement of $\mathrm{K}$ feldspar in the host rocks. $\mathrm{Fe}_{2} \mathrm{O}_{3}$ (tot) shows a weak negative correlation $\mathrm{CaO}(r=-0.48)$ with, reflecting the replacement of carbonate during jasperoid formation. $\mathrm{Mn}$ and $\mathrm{Fe}_{2} \mathrm{O}_{3}$ (tot) are negatively correlated $(r=-0.52)$ reflecting the geochemical fractionation of $\mathrm{Fe}$ and $\mathrm{Mn}$ in the hydrothermal precipitates.

The weak positive correlation between $\mathrm{SiO}_{2}$ and $\mathrm{Fe}_{2} \mathrm{O}_{3}$ contrasts with the strong negative correlation between $\mathrm{SiO}_{2}$ and $\mathrm{MnO}$. The weak correlation between $\mathrm{SiO}_{2}$ and $\mathrm{Fe}_{2} \mathrm{O}_{3}$ is due to the co-precipitation of $\mathrm{Si}$ and $\mathrm{Fe}$ during jasperoid formation. This correlation can also due to the weak adsorption of $\mathrm{SiO}_{2}$ on iron oxides (Anderson and Benjamin, 1985; Taylor, 1995; Pokrovski et al., 2003).

\section{Trace elements}

Trace element contents of MdM jasperoids are highly variable (Table 4). In comparison to the upper continental crust, samples exhibit a general enrichment in elements such as $\mathrm{Ba}(<96620 \mathrm{ppm})$, $\mathrm{Sr}(<1999 \mathrm{ppm})$, As (103 ppm), Cr (<640 ppm), Mo (>100 ppm), Sb $(<10.4 \mathrm{ppm}), \mathrm{Ge}(<26 \mathrm{ppm}), \mathrm{Ni}(<110 \mathrm{ppm}), \mathrm{Zn}(<140 \mathrm{ppm})$, and $\mathrm{Cu}$ $(<200 \mathrm{ppm})$, and are depleted in elements such as $\mathrm{Pb}(<12 \mathrm{ppm}), \mathrm{Sn}$ (<1 ppm), Ta $(<0.1 \mathrm{ppm})$, Th $(<0.6 \mathrm{ppm})$ and $\mathrm{Rb}(<29 \mathrm{ppm})$ (Figure 9). Co (15 ppm), W (<4 ppm) and V (<128 ppm) have average values close to those of the upper continental crust.

Most trace elements ( $\mathrm{Ba}, \mathrm{Ni}, \mathrm{Co}, \mathrm{Zn}, \mathrm{Cu}, \mathrm{Ga}, \mathrm{U}, \mathrm{Mo}$ and $\mathrm{As}$ ) in the $\mathrm{MdM}$ jasperoids are particularly enriched in the manganiferous jasperoids. In fact, the most trace element-rich samples (MM-105A; MM-101; MMT-1) are those with the highest Mn content (Table 2). Sample MM-108, the most hematite-rich sample (Table 1), is depleted in trace elements compared with the Mn-rich samples, which suggests a control of the trace elements content by Mn oxides. Among the trace metals, only $\mathrm{Cr}$ shows preference for the hematitic jasperoids. The enrichment of $\mathrm{Cr}$ in the hematitic jasperoids is consistent with the one reported in Fe-rich hydrothermal precipitates 

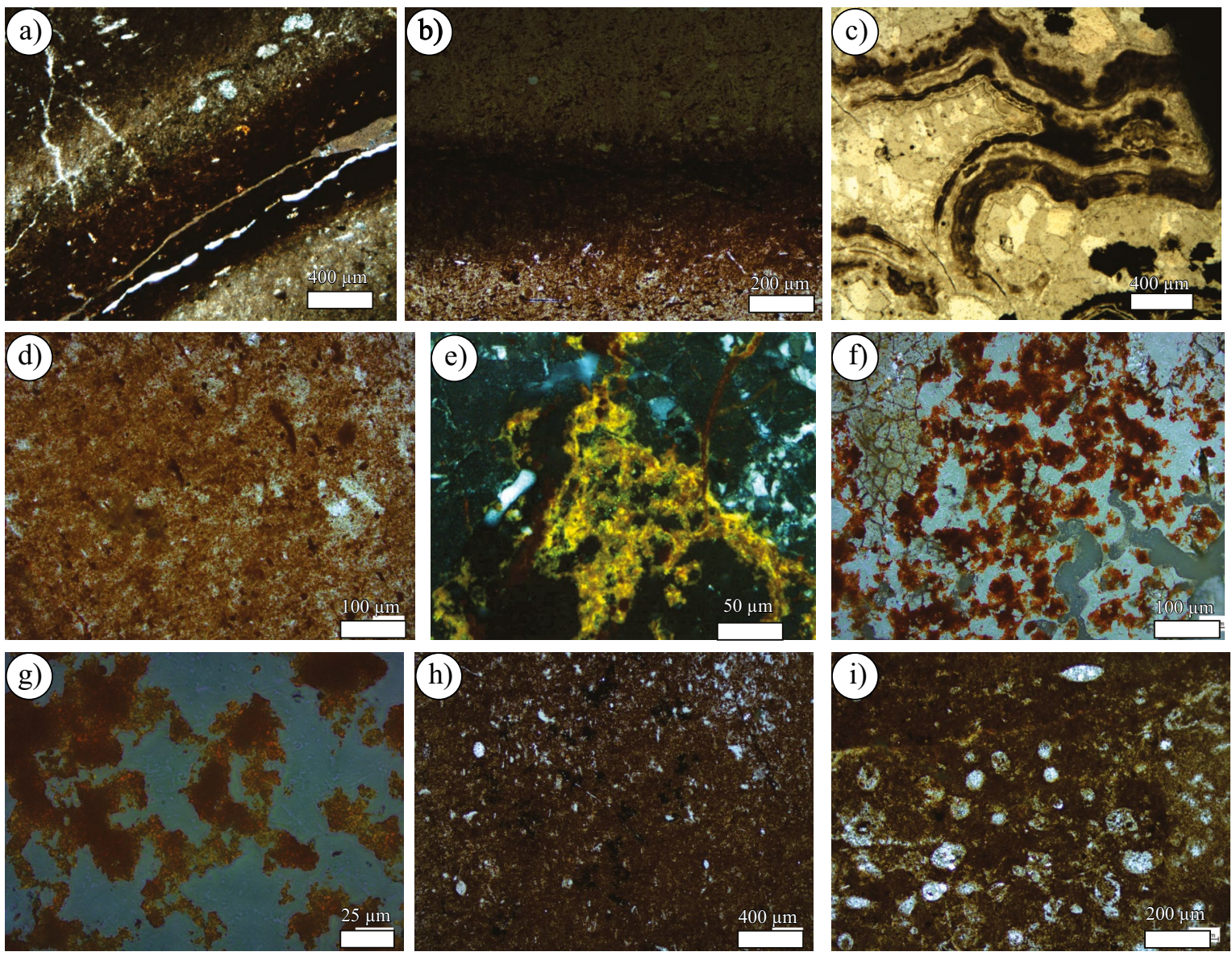

Figure 7. Photomicrographs showing the mineralogical and textural characteristics of jasperoids from the Montaña de Manganeso deposit. (a, b) Fe-rich and Fe-poor bands of a partially silicified limestone. The jasperoid still preserves some textures of the original host rock. (c) Colloform Mn oxides co-precipitated with chalcedony. (d) Disseminated and uniformly distributed fine-grained hematite. (e) Goethite and minor hematite in a quartz matrix. (f, g) Globular aggregates of hematite. (h) Deformed spherical recrystallized skeletons of radiolarians co existing with Fe-Mn oxides. (i) Close up of (h) showing radiolarians and other fossil remains.

(hydrothermal ironstones) of the Pacific seamounts (Hein et al., 1997).

Elevated $\mathrm{Ba}$ and $\mathrm{Sr}$ concentrations of the MdM jasperoids reflect the occurrence of barite in veinlets. Barium is also a dominant tunnel cation in manganese oxide minerals such as hollandite (Miura et al., 1987). High $\mathrm{Ni}$ and moderate $\mathrm{Zn}$ concentrations in samples MM 101 and MM 105A are consistent with enrichment of these elements in hydrothermal manganese rich deposits (Hein et al., 1997). Zinc concentrations are similar to those reported in other jasperoids of the Central Plateau (Labarthe-Hernandez et al., 1992). Low $\mathrm{Pb}$ and $\mathrm{Cu}$ concentrations indicate lack of sulfides in the deposit or significant sulfide precipitation at greater depths (e.g. Hein et al., 2000).

$\mathrm{Co}$ and $\mathrm{Ni}$ show a good correlation with $\mathrm{Zn}(r=0.91$ and 0.64 , respectively; Table 5), as has been reported for other $\mathrm{Mn}$-rich deposits (Hein et al., 2000). Similarly, Mo and V are correlated with Ba $(r=0.92$ and 0.99 , respectively; Table 5), which suggests that these metals probably occur in minerals that co-precipitated (e.g. McLemore et al., 1999). The lack of correlation between $\mathrm{Cu}$ and $\mathrm{Pb}$ with $\mathrm{Zn}(r=0.02$ and 0.33 , respectively; Table 5) is further evidence of absence of sulfides (chalcopyrite, galena, sphalerite) or at least lack of co-precipitation (e.g. Hein et al., 2000).

\section{REE geochemistry}

Total REE ( $\Sigma$ REE) contents are low, ranging from 7.7 to $55.2 \mathrm{ppm}$, with an average of $26.9 \mathrm{ppm}$ (Table 6). Samples are enriched in LREE compared with MREE $\left(\mathrm{La}_{\mathrm{CN}} / \mathrm{Sm}_{\mathrm{CN}}\right.$ ratio $=2.47$ to 6.47$)$ and HREE $\left(\mathrm{La}_{\mathrm{CN}} / \mathrm{Yb}_{\mathrm{CN}}=1.71\right.$ to 10.33$)$. MREE are just slightly enriched over HREE $\left(\mathrm{Gd}_{\mathrm{CN}} / \mathrm{Yb}_{\mathrm{CN}}=0.43\right.$ to 3.00$)$; however, samples MM-108 and MM-13 show a marked enrichment in HREE. Ce anomalies are negative, ranging from 0.2 to 0.8 , whereas $\mathrm{Y}$ anomalies ( $\mathrm{Y}_{\text {PASS }} / \mathrm{Ho}_{\text {PAAS }}$ ) range from 0.37 to 1.47 . Eu anomalies are variable, ranging from 0.6 to 1.7.

\section{DISCUSSION}

Silica-rich precipitates such as jaspers, bedded cherts, hydrothermal cherts and syngenetic cherts are often difficult to differentiate macroscopically (Baltuck, 1982). Most silica-rich precipitates, however, frequently contain non-silica phases whose mineralogy and geochemical signature can be used to determine the origin of the precipitates and thus differentiate them (Jones and Murchey, 1986; Murray, 1994). The mineralogy, chemical composition and element associations of the MdM jasperoids are therefore investigated to shed new light on their conditions of formation and origin.

\section{Geochemical signatures}

The major- and trace-elements chemistry of the MdM jasperoids is characterized by high $\mathrm{Si}$, Fe and $\mathrm{Mn}$ contents and low trace element concentrations. The latter reflects the low compatibility of quartz 

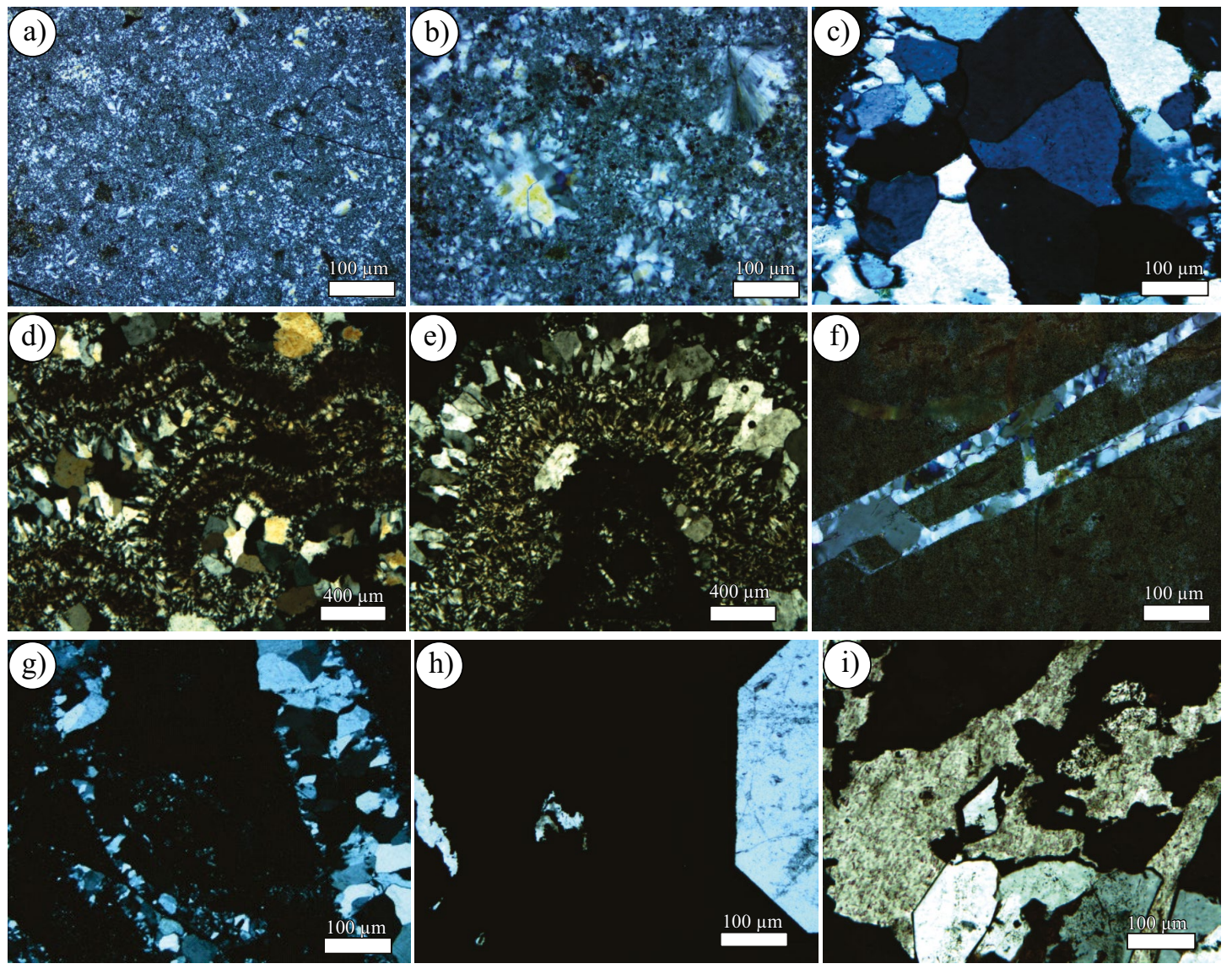

Figure 8. Photomicrographs showing the different quartz textures in the jasperoids of the Montaña de Manganeso deposit: (a) Cryptocrystalline quartz. (b) Microcrystalline quartz. (c) Coarse crystalline quartz. (d, e) Chalcedony transitioning to anhedral crystalline quartz, forming concentric colloform banding. (f, g) Quartz veins crosscut a jasperoid sample. The fractures are filled by a thin layer of first generation of microcrystalline quartz followed by coarse crystalline quartz. (h) Rare euhedral quartz grains. (i) Coarse crystalline quartz, consisting of crystals with planar and curved contacts. The dark dots are pores within the quartz crystals. Fe-Mn oxides particles replace different generations of quartz and fill spaces between quartz grain boundaries.

to incorporation of impurities (Heaney, 1994; Renault et al., 1995; McLemore et al., 1999). Unlike jasperoids from the southwest USA that are commonly associated with Carlin-type deposits (Nelson, 1990; Theodore and Jones, 1992; Arehart, 1996), the analyzed jasperoids from the MdM have high concentrations of manganese oxides and a depleted base metal content. Nonetheless, they have lower overall abundances of $\mathrm{Sb}$, As, and Au than the Carlin type deposits (Theodore and Jones, 1992; Arehart, 1996; Stenger et al., 1998). Due to their enrichment in $\mathrm{As}, \mathrm{Sb}, \mathrm{Zn}, \mathrm{Mo}, \mathrm{Ni}$, and $\mathrm{Cr}$, the jasperoids from the MdM have a geochemical signature more similar to that of submarine hydrothermal manganese deposits (Hein et al., 1997, 2000).

A striking geochemical characteristic of the MdM jasperoids is the

Table 1. Results of powder X-ray diffraction (XRD) analysis showing major mineralogical compositions and their abundance (weight percent, semiquantitative).

\begin{tabular}{|c|c|c|c|c|c|c|c|c|c|c|c|}
\hline \multirow[b]{2}{*}{ Mineral } & \multicolumn{2}{|c|}{ Manganese ore } & \multicolumn{4}{|c|}{ Black jasperoids } & \multicolumn{5}{|c|}{ Red jasperoids } \\
\hline & MM 105A & MM 103 & MM 25C & MM T2 & MM 106A & MM 101 & MM 13 & MM 202 & MM 203 & MM 108 & MM 23 \\
\hline Hematite & & & 9 & & 2 & 2 & 5 & 6 & 2 & 16 & 2 \\
\hline Magnetite & & 15 & & & & & & & & & \\
\hline Goethite & 11 & & 3 & & & & & & & & \\
\hline Quartz & & 21 & 71 & 98 & 78 & 71 & 92 & 77 & 94 & 84 & 90 \\
\hline Cristobalite & & & & & & 5 & & & & & \\
\hline Tridymite & & & & & & 12 & & & & & \\
\hline Pyrite & & 25 & & & & & & 17 & 4 & & \\
\hline Barite & & & & & 5 & & 3 & & & & \\
\hline Hollandite & & 39 & & & 11 & & & & & & \\
\hline Pyrolusite & 78 & & 17 & & 4 & 10 & & & & & \\
\hline Todorokite & & & & 2 & & & & & & & \\
\hline Birnessite & 11 & & & & & & & & & & \\
\hline
\end{tabular}


Table 2. Summary of major element concentrations. For the chemical ratios calculations, atomic contents were recalculated from element concentrations (wt\%).

\begin{tabular}{|c|c|c|c|c|c|c|c|c|c|c|c|c|c|c|c|c|}
\hline & $\mathrm{SiO}_{2}$ & $\mathrm{Al}_{2} \mathrm{O}_{3}$ & $\mathrm{Fe}_{2} \mathrm{O}_{3}{ }^{\mathrm{T}}$ & $\mathrm{MnO}$ & $\mathrm{MgO}$ & $\mathrm{CaO}$ & $\mathrm{Na}_{2} \mathrm{O}$ & $\mathrm{K}_{2} \mathrm{O}$ & $\mathrm{TiO}_{2}$ & $\mathbf{P}_{2} \mathrm{O}_{5}$ & LOI & Total & $\mathrm{Fe} / \mathrm{Mn}$ & $\begin{array}{c}(\mathbf{F e}+\mathbf{M n}) / \\
\mathrm{Ti}\end{array}$ & $\begin{array}{c}\mathrm{Al} / \\
(\mathrm{Al}+\mathrm{Mn}+\mathrm{Fe})\end{array}$ & $\mathrm{Si} / \mathrm{Al}$ \\
\hline MM-106A & 75.92 & 0.50 & 7.72 & 12.44 & 0.08 & 0.1 & $<0.01$ & 0.04 & 0.002 & 0.03 & 3.07 & 99.84 & 0.56 & 12539.26 & 0.02 & 134.12 \\
\hline MM-13 & 84.32 & 0.24 & 13.21 & 0.08 & 0.02 & 0.03 & $<0.01$ & 0.02 & 0.012 & 0.02 & 0.55 & 98.42 & 152.95 & 1292.79 & 0.01 & 310.32 \\
\hline MM-202 & 71.86 & 0.24 & 15.64 & 7.26 & 0.07 & 0.24 & 0.03 & 0.05 & 0.001 & 0.10 & 2.08 & 97.57 & 1.95 & 27628.42 & 0.01 & 264.47 \\
\hline MM-203 & 83.98 & 0.82 & 9.22 & 3.53 & 0.10 & 0.18 & 0.10 & 0.08 & 0.035 & 0.15 & 1.73 & 99.92 & 2.36 & 437.69 & 0.05 & 90.46 \\
\hline MM-105A & 1.52 & 0.40 & 1.31 & 72.20 & 0.04 & 0.34 & 0.15 & 0.36 & 0.001 & 0.27 & 12.35 & 88.93 & 0.02 & 94803.55 & 0.00 & 3.36 \\
\hline MMT-I & 10.07 & 0.47 & 4.30 & 57.68 & 0.16 & 0.50 & 0.20 & 0.42 & 0.002 & 0.18 & 12.05 & 86.04 & 0.07 & 39766.88 & 0.01 & 18.92 \\
\hline
\end{tabular}

preferential enrichment of most trace elements $(\mathrm{Ba}, \mathrm{Ni}, \mathrm{Co}, \mathrm{Zn}, \mathrm{Cu}$, $\mathrm{Ga}, \mathrm{U}, \mathrm{Mo}$ and As) in the manganiferous jasperoids. At near neutral $\mathrm{pH} \mathrm{Mn}$ oxides have a stronger adsorption capacity for cations than Fe oxides, as cationic species are attracted to the negatively charged surface of Mn oxides (McKenzie, 1980; Hein et al., 1997; Suda and Makino, 2016). This implies that the cationic signature of the MdM jasperoids is strongly dependent on the concentration of Mn oxides in these jasperoids. Iron oxides, on the other hand, will preferentially adsorb neutral and negatively charged species, due to the slightly positive charge of the hydrated Fe oxide surfaces (Koschinsky and Halbach, 1995; Hein et al., 1997, 2005). Trace elements that commonly form anions or oxyanions such as $\mathrm{Cr}$, As, $\mathrm{V}$ and $\mathrm{P}$ therefore generally characterize $\mathrm{Fe}$-rich hydrothermal precipitates (ironstones) (Hein et al., 1997).

Adsorption of oppositely charged species by Fe-Mn oxyhydroxides alone cannot account for the preferential enrichment in the manganiferous jasperoids of MdM of some trace elements such as Mo and As. These elements commonly form negatively charged species such as the molybdate and arsenate (or arsenite) oxyanions, respectively and as such are expected to be enriched in the hematitic jasperoids. The depletion of trace elements in the hematitic jasperoids can additionally be explained by adsorption of silica on the surfaces of the Fe oxyhydroxides, decreasing significantly the number of available sorption sites, and thus reducing the incorporation of other anions and cations (Anderson and Benjamin, 1985; Taylor, 1995; Pokrovski et al., 2003). Further, depletion of trace elements in the hematitic jasperoids might be an indication that $\mathrm{Fe}$ was initially precipitated mainly as pyrite (Lovering, 1972). As Mn oxides have higher adsorption capacity of trace elements than pyrite, the hematite rich samples do not present the same trace element enrichment equal to that of manganese oxides rich samples. For As in particular, the preferential enrichment in the manganiferous jasperoids, despite higher affinity of As for iron oxides (Manning et al., 2002; Ouvrard et al., 2005; Ying et al., 2012; Zhang et al., 2014; Bai et al., 2016), can be explained by inhibition of As adsorption on hematite by carbonate species during replacement of the host rocks (e.g. Brechbühl et al., 2012).

\section{Source of silica and Fe-Mn oxides}

Determination of the sources or origin of $\mathrm{SiO}_{2}, \mathrm{Fe}$ and $\mathrm{Mn}$ is fundamental to understanding the genesis of the MdM jasperoids. Major potential sources of silica include biogenic, diagenetic, detrital and hydrothermal (Sugisaki et al., 1982; Adachi et al., 1986; Yamamoto, 1986), whereas for manganese and iron oxides they can be hydrothermal, hydrogenetic and diagenetic in origin (Roy, 1981, 1997). At MdM, field, petrographic and geochemical evidence indicate that hot hydrothermal solutions ascending from depths along faults and fractures supplied at least part of the silica and Fe-Mn for jasperoid formation.
Steep dipping faults and fractures lined with silicified Fe and Mn oxides characterize the MdM (Figure 3g). The rocks around the faults and fractures present different degrees of silicification. Those nearest to the fractures are completely silicified and those furthest are only partially silicified and still preserve textures of the original host rock (Figure 7a). Some of the jasperoids have associated zones of argillic alteration and stockwork that can be interpreted as feeder channel ways for upwelling hydrothermal fluids. These structural and alteration features suggest flow of ascending Fe-Mn bearing, silica-rich hydrothermal fluids through the host rock.

The MdM jasperoids also exhibit textural features indicating their formation from hot hydrothermal solutions. Textural evidence such as dehydration cracks and growth patterns suggest crystallization from amorphous silica (Figures 7, 8), with poorly crystalline cristobalite and tridymite as intermediate phases (McKay and Finlow-Bates, 1977; Fournier, 1985; Heaney, 1994). Silica appears to have crystallized episodically within open spaces initially, with replacement and silicification of host rocks becoming more pervasive in the later stages. Episodic deposition of silica and Fe-Mn oxides led to the formation of highly brecciated jasperoids. Although some jasperoids are roughly laminated and locally contain radiolarians, a biogenic origin of the jasperoids is unlikely. The lamination probably resulted from deposition as gel and variations in the physico-chemical conditions of the hydrothermal fluid during precipitation (Chi Fru et al., 2018).

The geochemical signature of the jasperoids also suggest that silicification was the result of hydrothermal activity. They display enrichment in the concentrations of the typically hydrothermal elements such as $\mathrm{Ba}, \mathrm{Sr}, \mathrm{As}, \mathrm{Cr}, \mathrm{Mo}, \mathrm{Sb}, \mathrm{Ni}, \mathrm{Zn}$, and $\mathrm{Cu}$, and are strongly depleted in the elements indicative of clastic input such as $\mathrm{Ti}, \mathrm{K}$, Th and

Table 3. Correlation coefficient $(r)$ matrix of various major elements of the Montaña de Manganeso jasperoids.

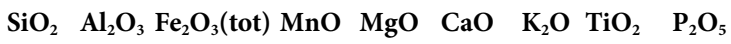

\begin{tabular}{lrrrrrrrrr}
\hline $\mathrm{SiO}_{2}$ & 1.00 & & & & & & & & \\
$\mathrm{Al}_{2} \mathrm{O}_{3}$ & -0.02 & 1.00 & & & & & & & \\
$\mathrm{Fe}_{2} \mathrm{O}_{3}$ (tot) & 0.38 & -0.46 & 1.00 & & & & & & \\
$\mathrm{MnO}$ & -0.98 & 0.06 & -0.55 & 1.00 & & & & & \\
$\mathrm{MgO}$ & 0.00 & 0.94 & -0.52 & 0.05 & 1.00 & & & & \\
$\mathrm{CaO}$ & 0.01 & 0.81 & -0.48 & 0.05 & 0.93 & 1.00 & & & \\
$\mathrm{~K}_{2} \mathrm{O}$ & -0.41 & 0.72 & -0.70 & 0.49 & 0.83 & 0.89 & 1.00 & & \\
$\mathrm{TiO}_{2}$ & 0.33 & 0.66 & 0.05 & -0.35 & 0.48 & 0.34 & 0.16 & 1.00 & \\
$\mathrm{P}_{2} \mathrm{O}_{5}$ & -0.83 & -0.14 & -0.14 & 0.79 & -0.24 & -0.18 & 0.18 & -0.12 & 1.00 \\
\hline
\end{tabular}


Table 4. Trace element composition of the jasperoids from the Montaña de Manganeso deposit.

\begin{tabular}{|c|c|c|c|c|c|c|c|c|c|c|c|c|c|c|c|c|c|c|c|c|c|c|c|c|c|c|}
\hline & Sc & $\mathbf{V}$ & $\mathrm{Ba}$ & $\mathrm{Sr}$ & $\mathbf{Y}$ & $\mathrm{Zr}$ & $\mathrm{Cr}$ & Co & $\mathrm{Ni}$ & $\mathrm{Cu}$ & Zn & $\mathrm{Tl}$ & $\mathrm{Ge}$ & As & $\mathbf{R b}$ & $\mathrm{Nb}$ & Mo & Ag & Sn & Sb & Cs & Hf & $\mathrm{W}$ & $\mathbf{P b}$ & Th & $\mathbf{U}$ \\
\hline & \multicolumn{26}{|c|}{ ppm } \\
\hline MM-106A & $<1$ & 22 & 4017 & 70 & 4 & 3 & 280 & 3 & 20 & 200 & 30 & $<0.1$ & 5 & 29 & $<2$ & $<1$ & 13 & $<0.5$ & $<1$ & 0.8 & $<0.5$ & $<0.2$ & $<1$ & $<5$ & $<0.1$ & 0.6 \\
\hline MM-13 & $<1$ & 40 & 17310 & 180 & $<1$ & 5 & 640 & 1 & $<20$ & $<10$ & $<30$ & $<0.1$ & 6 & 8 & $<2$ & $<1$ & 24 & $<0.5$ & $<1$ & 2.4 & $<0.5$ & $<0.2$ & 1 & $<5$ & 0.2 & 0.2 \\
\hline MM-202 & $<1$ & 58 & 7246 & 145 & 3 & $<2$ & 330 & 3 & 50 & 40 & 90 & $<0.1$ & 6 & 74 & $<2$ & $<1$ & 13 & $<0.5$ & $<1$ & 4 & $<0.5$ & $<0.2$ & 3 & 5 & $<0.1$ & 1 \\
\hline MM-203 & 1 & 54 & 3741 & 105 & 9 & 12 & 330 & 3 & 30 & 20 & 40 & $<0.1$ & 5 & 28 & 2 & $<1$ & 6 & $<0.5$ & $<1$ & 1.7 & 0.9 & 0.2 & $<1$ & $<5$ & 0.3 & 0.4 \\
\hline MM-105A & 2 & 102 & 43710 & 1999 & 14 & 4 & $<20$ & 11 & 70 & 50 & 140 & 0.1 & 7 & 103 & $<2$ & $<1$ & 100 & $<0.5$ & $<1$ & 10.4 & $<0.5$ & $<0.2$ & 2 & 12 & $<0.1$ & 3.9 \\
\hline MMT-I & $<1$ & 102 & 24480 & 1519 & 19 & 3 & $<20$ & 8 & 80 & 80 & 120 & $<0.1$ & 7 & 78 & 2 & $<1$ & 39 & $<0.5$ & 1 & 2.1 & $<0.5$ & $<0.2$ & $<1$ & 5 & $<0.1$ & 5.2 \\
\hline
\end{tabular}

Zr (Brusnitsyn and Zhukov, 2012, 2018) (Figure 9). The abundance of $\mathrm{Fe}-\mathrm{Mn}$ oxides and the depletion of $\mathrm{Al}$ and $\mathrm{Ti}$ oxides suggest a role for hydrothermal activity (Adachi et al., 1986; Yongzhang et al., 1994; Jun et al., 2010).

The $\mathrm{Fe} / \mathrm{Mn}$ ratios for the MdM jasperoids vary widely from 0.02 to 152.95 , typical of hydrothermal precipitates which vary from about 24000 for hydrothermal seamount ironstones to about 0.001 for hydrothermal stratabound manganese oxides from active volcanic arcs (Hein et al., 1997). In contrast, hydrogenetic precipitates vary within a restricted range close to unity: from 0.7 for open-ocean seamount crusts to 1.2 for continental margin seamount crusts (Hein et al., 1997). The $(\mathrm{Fe}+\mathrm{Mn}) / \mathrm{Ti}$ ratio $(<94803)$ is also remarkably high, indicating a hydrothermal formation for the jasperoids (Boström et al., 1973; Cronan, 1980; Brusnitsyn and Zhukov, 2012, 2018). These values can be contrasted with metalliferous sediments deposited distal to hydrothermal vents and composed of mostly clastic and biogenic material with $(\mathrm{Fe}+\mathrm{Mn}) / \mathrm{Ti}$ ratio between 68 to 770 (Brusnitsyn and Zhukov, 2012). The extremely high values of the $(\mathrm{Fe}+\mathrm{Mn}) / \mathrm{Ti}$ ratio for the MdM samples partly reflect transition of some manganiferous jasperoids to $\mathrm{Mn}$ ore. The low $\mathrm{Al} /(\mathrm{Al}+\mathrm{Fe}+\mathrm{Mn})$ ratio for the MdM jasperoids (0.01-0.05 with one anomalous value of 0.45$)$ likewise suggests predominant hydrothermal source. The $\mathrm{Al} /(\mathrm{Al}+\mathrm{Fe}+\mathrm{Mn})$ ratio of siliceous rocks ranges from as low as 0.01 for pure hydrothermal precipitates to as high as 0.60 for pure pelagic biological precipitates (Adachi et al., 1986; Yamamoto, 1986).

The element ratios discussed so far are commonly coupled with discrimination diagrams to differentiate between hydrothermal, hydrogenous and diagenetic silica rich deposits (Adachi et al., 1986; Yamamoto, 1986; Yongzhang et al., 1994). For the Fe-Mn rich type additional discrimination diagrams have also been proposed (Bonatti et al., 1972; Toth, 1980; Choi and Hariya, 1992; Nicholson, 1992; Conly et al., 2011; Bau et al., 2014). These diagrams are adapted here to determine the sources of silica and Fe-Mn oxides for the MdM jasperoids (Figure 10). Uranium and Th concentrations of the MdM jasperoids are comparable to those of cherts of hydrothermal origin (Crerar et al., 1982; Hein et al., 1987; Flohr and Huebner, 1992), and effectively plot within or close to the hydrothermal field of Bonatti et al. (1976) on the U-Th binary diagram (Figure 10a). On the Fe-Mn-Al, Ni-Co-Zn and $\mathrm{Fe}-\mathrm{Mn}-(\mathrm{Co}+\mathrm{Ni}+\mathrm{Cu})$ ternary diagrams all samples also fall within the hydrothermal field (Figure 10b-10d).

The chondrite-normalized REE patterns $\left(\mathrm{REE}_{\mathrm{CN}}\right)$ (Figure 11) of the jasperoid samples are characterized by a general decrease in normalized concentrations from LREE to HREE and have well-defined negative Ce anomalies typical of hydrothermal $\mathrm{Fe}-\mathrm{Mn}$ oxide deposits precipitated under oxidizing conditions (Crerar et al., 1982; Wright et al., 1987; Öztürk and Hein, 1997; Usui and Someya, 1997; Sinisi et al., 2012; Öksüz

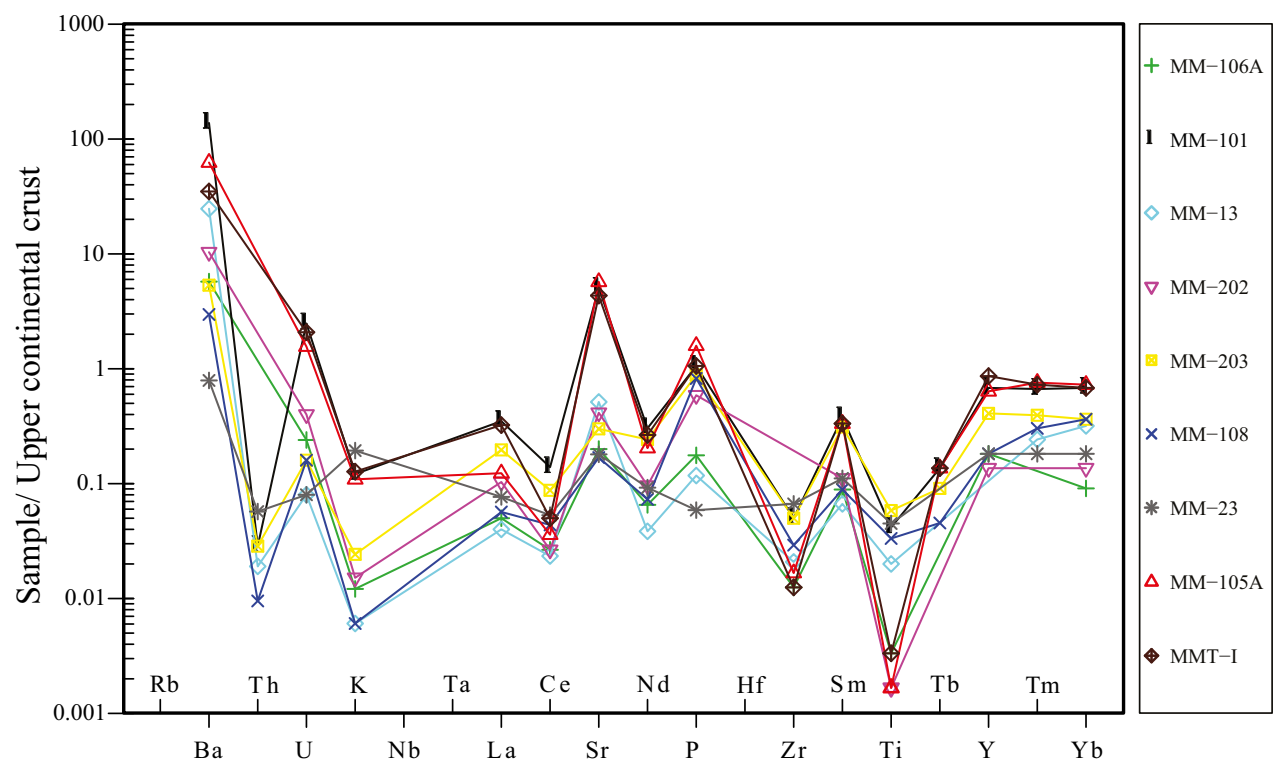

Figure 9. The Upper Continental Crust (Taylor and McLennan, 1985) normalized elemental distribution pattern of the Montaña de Manganeso jasperoids. 
Table 5. Correlation coefficient $(r)$ matrix of various trace elements of the Montaña de Manganeso jasperoids.

\begin{tabular}{lcccccccccccccc}
\hline & $\mathbf{V}$ & $\mathbf{B a}$ & $\mathbf{S r}$ & $\mathbf{Z r}$ & $\mathbf{C r}$ & $\mathbf{C o}$ & $\mathbf{N i}$ & $\mathbf{C u}$ & $\mathbf{Z n}$ & As & Mo & Pb & Th & U \\
\hline $\mathrm{V}$ & 1.00 & & & & & & & & & & & & \\
$\mathrm{Ba}$ & 0.99 & 1.00 & & & & & & & & & & & \\
$\mathrm{Sr}$ & 0.31 & 0.34 & 1.00 & & & & & & & & & & \\
$\mathrm{Zr}$ & 0.38 & 0.31 & -0.07 & 1.00 & & & & & & & & & \\
$\mathrm{Cr}$ & 0.67 & 0.68 & 0.74 & 0.22 & 1.00 & & & & & & & & & \\
$\mathrm{Co}$ & 0.06 & 0.08 & 0.93 & -0.13 & 0.68 & 1.00 & & & & & & & \\
$\mathrm{Ni}$ & 0.58 & 0.62 & 0.57 & 0.02 & 0.47 & 0.40 & 1.00 & & & & & & \\
$\mathrm{Cu}$ & -0.42 & -0.37 & 0.05 & -0.44 & -0.41 & 0.11 & -0.08 & 1.00 & & & & & \\
$\mathrm{Zn}$ & 0.25 & 0.27 & 0.93 & 0.10 & 0.71 & 0.91 & 0.64 & 0.02 & 1.00 & & & & \\
$\mathrm{As}$ & 0.23 & 0.25 & 0.84 & 0.17 & 0.56 & 0.81 & 0.70 & 0.11 & 0.96 & 1.00 & & & & \\
$\mathrm{Mo}$ & 0.92 & 0.92 & 0.51 & 0.17 & 0.68 & 0.25 & 0.56 & -0.26 & 0.33 & 0.28 & 1.00 & & & \\
$\mathrm{~Pb}$ & 0.57 & 0.52 & 0.44 & 0.55 & 0.45 & 0.29 & 0.27 & -0.09 & 0.33 & 0.33 & 0.67 & 1.00 & & \\
$\mathrm{Th}$ & 0.46 & 0.45 & -0.18 & 0.49 & 0.03 & -0.35 & -0.08 & 0.20 & -0.18 & -0.11 & 0.35 & 0.41 & 1.00 & \\
$\mathrm{U}$ & 0.85 & 0.87 & 0.36 & 0.19 & 0.56 & 0.12 & 0.80 & -0.44 & 0.36 & 0.40 & 0.77 & 0.27 & 0.13 & 1.00 \\
\hline
\end{tabular}

and Okuyucu, 2014; Maghfouri et al., 2017). Positive Ce anomalies in Fe-Mn deposits are regarded as typical of hydrogenetic precipitation (Choi and Hariya, 1992; Canet et al., 2008; Josso et al., 2017).

Yttrium anomalies ( $\mathrm{Y}_{\text {PASS }} / \mathrm{Ho}_{\text {PASS }}$ ) of the MdM jasperoid samples are mostly positive, with the exception of two samples (Table 6). Positive $\mathrm{Y}$ anomalies ( $\mathrm{Y}_{\text {PASS }} / \mathrm{Ho}_{\text {PASS }}>1$ ) are typical of hydrothermal Fe-Mn deposits whereas hydrogenetic and diagenetic Mn deposits form negative anomalies ( $\left.\mathrm{Y}_{\mathrm{PASS}} / \mathrm{Ho}_{\mathrm{PASS}}<1\right)$ (Bau et al., 2014).

\section{Genesis of the Montaña de Manganeso jasperoids}

The great amounts of quartz, cristobalite and tridymite which form the MdM jasperoids suggest that cooling of ascending hot hydrothermal fluids was the primary mechanism for the formation of the jasperoids (Fournier, 1985; Heaney, 1994; Hedenquist et al., 2000). In the near surface environment, cooling of silica-rich hydrothermal fluids is known to precipitate amorphous silica which then transitions to quartz through intermediate, metastable polymorphs such as opal-CT, cristobalite and tridymite (Fournier, 1985; Canet et al., 2005).

It is known that the replacement of limestone by silica, generally necessary for jasperoid formation (Lovering, 1972 ), can be achieved during cooling of a solution with a circumneutral $\mathrm{pH}$ in the near surface environment (Fournier, 1985). The retrograde solubility of calcite and the prograde solubility of quartz below $300^{\circ} \mathrm{C}$ enables the replacement. Boiling is not an ideal mechanism for jasperoid formation, as it is more likely to lead to deposition of calcite, which is counterproductive to the replacement of calcite by silica (Lovering, 1972; Theodore and Jones, 1992). However, as calcite is abundant at MdM and the host rocks are predominantly sandstones and shale with only remnant carbonate rocks present, it is possible that boiling played a role in jasperoid formation.

Field and petrological observations suggest that iron mineralization preceded manganese mineralization. The replacement of iron oxides by manganese oxides observable throughout the deposit suggests an early deposition of Fe minerals and the inflow of a later Mn rich fluid. Manganese oxide bearing veins frequently cut the hematitic jasperoids, but the reverse is not common. The hematitic jasperoids originally deposited under reducing conditions and the manganiferous jasperoids were deposited later, under oxidizing conditions. The occurrence of pyrite, a common early mineral in jasperoids (Lovering, 1972), suggests that the oxidized iron minerals (hematite, goethite and magnetite) resulted from oxidation of pyrite (Schwertmann and Murad, 1983; Chi Fru et al., 2018). The existence of only manganese oxides with no $\mathrm{Mn}^{2+}$ bearing minerals indicates formation at a later stage, under oxidizing conditions.

A cooling intrusive at depth possibly served as the driving force for deep circulating hydrothermal fluids that deposited silica and FeMn oxides. Labarthe-Hernández et al. (1992) considered the felsic El Socorro intrusive, exposed about $55 \mathrm{~km}$ to the SW of the MdM, as the cause of the formation of the main known jasperoids of the region. The Cenozoic volcanism linked in certain parts of the Central Plateau to the volcanism of the Sierra Madre Occidental (Aranda-Gómez and Mcdowell, 1998; Aranda-Gómez et al., 2007; Tristán-González et al., 2008, 2009a; Aguillón-Robles et al., 2009; Rodríguez-Ríos et al., 2013) could have supplied the vast amounts of silica required for the formation of the jasperoid of the Central Plateau, including those of the MdM.

Table 6. Rare Eearth elements plus Ytrium (REY) compositions of the Montaña de Manganeso jasperoids. Eu, Ce and Y anomalies are also shown in Table 6.

\begin{tabular}{|c|c|c|c|c|c|c|c|c|c|c|c|c|c|c|c|c|c|c|c|}
\hline & $\mathbf{L a}$ & $\mathrm{Ce}$ & Pr & Nd & $\mathrm{Sm}$ & Eu & Gd & $\mathbf{T b}$ & Dy & Ho & Er & $\operatorname{Tm}$ & $\mathbf{Y b}$ & $\mathbf{L u}$ & $\mathbf{Y}$ & $\mathbf{Y}_{\text {PASS }} / \mathbf{H o}_{\text {PAAS }}$ & $\Sigma$ REE & $\mathbf{E u} / \mathbf{E} \mathbf{u}^{*}$ & $\mathrm{Ce} / \mathrm{Ce}^{\star}$ \\
\hline MM-101 & 10.5 & 8.9 & 1.72 & 7.9 & 1.7 & 1.11 & 2.4 & 0.3 & 1.9 & 0.4 & 1.4 & 0.22 & 1.5 & 0.22 & 15 & 1.38 & 55.2 & 1.7 & 0.5 \\
\hline MM-202 & 3.1 & 1.7 & 0.65 & 2.5 & 0.5 & 0.21 & 0.5 & 0.1 & 0.5 & 0.1 & 0.3 & 0.05 & 0.3 & 0.05 & 3 & 1.10 & 13.6 & 1.3 & 0.3 \\
\hline MM-203 & 5.9 & 5.6 & 1.45 & 6.3 & 1.4 & 0.38 & 1.5 & 0.2 & 1.4 & 0.3 & 0.8 & 0.13 & 0.8 & 0.14 & 9 & 1.10 & 35.3 & 0.8 & 0.5 \\
\hline MM-108 & 1.7 & 2.8 & 0.47 & 1.9 & 0.4 & 0.09 & 0.5 & 0.1 & 0.7 & 0.2 & 0.5 & 0.1 & 0.8 & 0.13 & 4 & 0.73 & 14.4 & 0.6 & 0.8 \\
\hline MMT-I & 9.7 & 3.2 & 1.49 & 6.9 & 1.5 & 0.62 & 2.1 & 0.3 & 2.2 & 0.5 & 1.6 & 0.24 & 1.5 & 0.25 & 19 & 1.39 & 51.1 & 1.1 & 0.2 \\
\hline
\end{tabular}


(a)

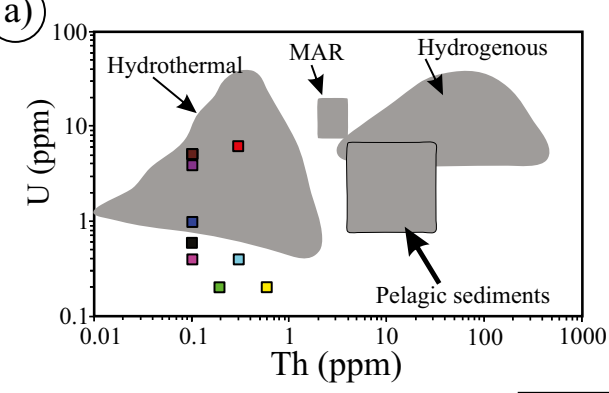

(b))

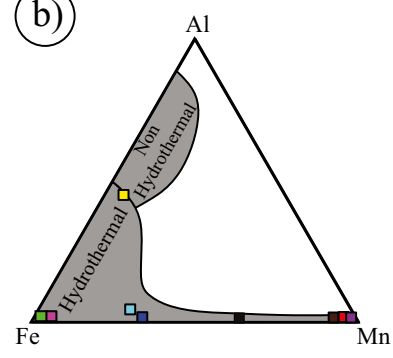

(c))

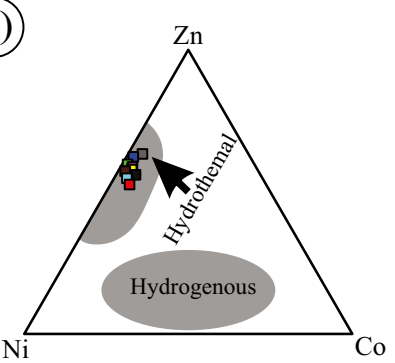

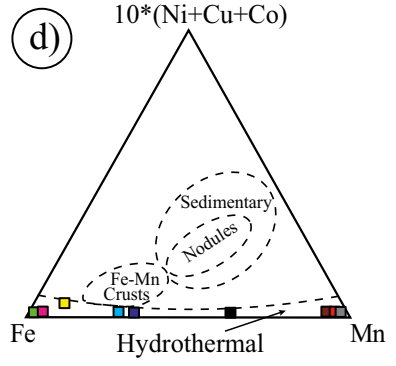

MM-106A $\square$ MM-101 $\square$ MM-13 $\square$ MM-202 $\square \mathrm{MM}-203 \square \mathrm{MM}-108 \square \mathrm{MM}-23 \square \mathrm{MM}-105 \mathrm{~A} \square \mathrm{MMT}-1$

Figure 10. Discriminating diagrams for the Montaña de Manganeso jasperoid samples. (a) U-Th discrimination diagram. The Montaña de Manganeso jasperoids fall within and close to the hydrothermal field. Fields after Bonatti et al., (1976). (b) AI-Fe-Mn ternary diagram showing the fields of hydrothermal and hydrogenous precipitates. The Montaña de Manganeso samples all fall within the hydrothermal field. Fields after Adachi et al. (1986) and Yamamoto (1987). (c) Zn-Ni-Co ternary diagram showing fields of hydrothermal and hydrogenous deposits. Fields after Choi and Hariya (1992). The Montaña de Manganeso samples all fall within the hydrothermal field. (d) On the $(\mathrm{Co}+\mathrm{Ni}+\mathrm{Cu})-\mathrm{Fe}-\mathrm{Mn}$ ternary diagram (fields after Bonatti et al., 1972; Toth, 1980) the Montaña de Manganeso samples also fall within the hydrothermal field.

\section{CONCLUSIONS}

The MdM jasperoids occur as primarily fault-controlled blocky and lenticular bodies of diverse sizes confined to NE-trending faults within strongly folded and fractured sedimentary and volcaniclastic rocks. There is field, petrographic and geochemical evidence that hot hydrothermal solutions ascending from depths along faults and fractures supplied silica and at least part of the manganese and iron oxides for jasperoid formation. The presence of a feeder fault system, wellmanifested differentiation of $\mathrm{Mn}$ from $\mathrm{Fe}$ and $\mathrm{Si}$, banded and brecciated jasperoids, with associated zones of argillic alteration strongly suggest formation by hydrothermal processes close to the paleosurface. Textural evidence indicates multiple episodes of replacement, brecciation, and veining by episodic injection of silica-rich hydrothermal fluids. The geochemical signature of the jasperoids also suggest that silicification was product of hydrothermal activity. Silica and Fe-Mn oxyhydroxides were likely precipitated from cooling ascending silica-rich hydrothermal fluids that evolved from reduced to oxidized. The hydrothermal fluids filled faults and fractures, and penetrated permeable horizons and replaced favorable units forming massive jasperoid bodies. The ascending hot hydrothermal solutions leached trace metals from the host rocks, part of which were scavenged by $\mathrm{Fe}$ and $\mathrm{Mn}$ oxides. An intrusive at depth probably served as a driving force for deep circulating hydrothermal fluids that deposited silica and Fe-Mn oxides.

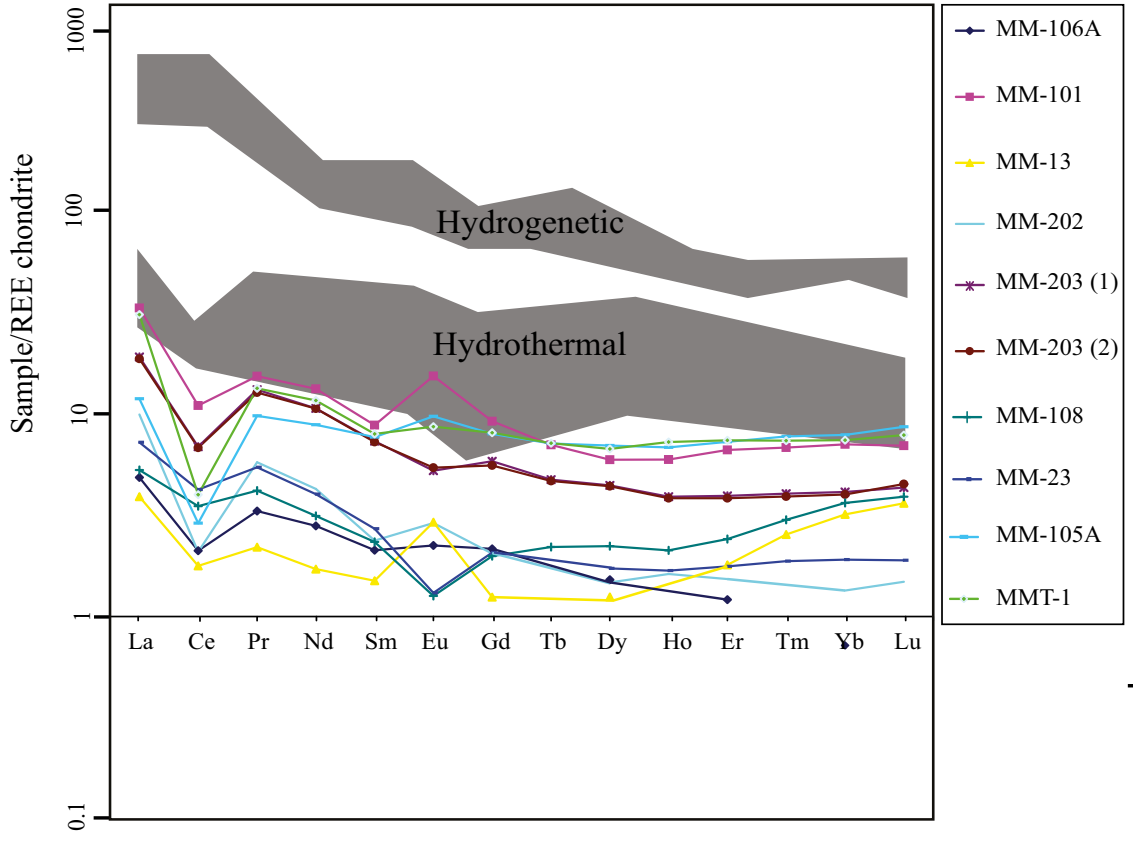

Figure 11. Chondrite normalized REE patterns displaying fields of hydrothermal and hydrogenetic deposits. The Montaña de Manganeso samples mostly fall below the hydrothermal field. 


\section{ACKNOWLEDGMENTS}

This paper is part of J. M's PhD thesis. J.M. acknowledges the support of CONACyT through a $\mathrm{PhD}$ scholarship. Funding for this work was provided by UNAM through research grant PAPIIT IG100116 to Eduardo González Partida. We would like to thank Teresa Pi Puig for the X ray diffraction analysis. Augusto Rodríguez Díaz is greatly thanked for help during fieldwork and for discussions on jasperoid formation. This manuscript was greatly improved thanks to the review by Jose Rafael Barboza-Gudiño and another anonymous reviewer. We also extend our appreciation to Dr. Ángel Nieto-Samaniego and Dr. Luca Ferrari for the editorial handling of this manuscript.

\section{REFERENCES}

Adachi, M., Yamamoto, K., Sugisaki, R., 1986, Hydrothermal chert and associated siliceous rocks from the northern Pacific. Their geological significance as indication of ocean ridge activity: Sedimentary Geology, 47, 125-148, https://doi.org/10.1016/0037-0738(86)90075-8

Aguillón-Robles, A., Tristán-González, M., Aguirre-Díaz, G.J., Bellon, H., 2009, Syn-extensional intra-plate trachydacite-rhyolitic dome volcanism of the Mesa Central, southern Sierra Madre Occidental volcanic province, Mexico: Journal of Volcanology and Geothermal Research 187, 33-52, https://doi.org/10.1016/j.jvolgeores.2009.08.021

Aguillón-Robles, A., Tristán-González, M., López-Doncel, R.A., García-Arreola, M.E., Almaguer-Rodríguez, J. de L., Maury, R.C., 2012, Trace elements geochemistry and origin of volcanic units from the San Luis Potosí and Río Santa María volcanic fields, Mexico: The bearing of ICP-QMS data: Geofísica Internacional, 51, 293-308.

Aguillón-Robles, A., Tristán-González, M., De Jesús Aguirre-Díaz, G., López-Doncel, R.A., Bellon, H., Martínez-Esparza, G., 2014, Eocene to Quaternary mafic-intermediate volcanism in San Luis Potosí, central Mexico: The transition from Farallon plate subduction to intra-plate continental magmatism: Journal of Volcanology and Geothermal Research, 276, 152-172, https://doi.org/10.1016/j.jvolgeores.2014.02.019

Aguirre-Díaz, G.J., Labarthe-Hernández, G., 2003, Fissure ignimbrites: Fissuresource origin for voluminous ignimbrites of the Sierra Madre Occidental and its relationship with Basin and Range faulting: Geology, 31, 773, https://doi.org/10.1130/G19665.1

Aguirre-Díaz, G.J., Labarthe-Hernández, G., Tristán-González, M., NietoObregón, J., Gutiérrez-Palomares, I., 2008, The Ignimbrite Flare-Up and Graben Calderas of the Sierra Madre Occidental, Mexico, in: Developments in Volcanology: Elsevier, 143-180, https://doi.org/10.1016/ S1871-644X(07)00004-6

Albinson F., T., 1988, Geologic reconstruction of paleosurfaces in the Sombrerete, Colorado, and Fresnillo districts, Zacatecas State, Mexico: Economic Geology, 83, 1647-1667, https://doi.org/10.2113/gsecongeo.83.8.1647

Alexandri, R.R., 1976, Estudio Geológico del Yacimiento Montaña de Manganeso: San Luis Potosí, Universidad Autónoma de San Luis Potosí, Bsc Thesis, 94 pp.

Anderson, P.R., Benjamin, M.M., 1985, Effects of Silicon on the Crystallization and Adsorption Properties of Ferric Oxides: Environmental Science and Technology, 19, 1048-1053, https://doi.org/10.1021/es00141a004

Aranda-Gómez, J.J., Mcdowell, F.W., 1998, Paleogene Extension in the Southern Basin and Range Province of Mexico: Syndepositional Tilting of Eocene Red Beds and Oligocene Volcanic Rocks in the Guanajuato Mining District: International Geology Review, 40, 116-134, https://doi. org/10.1080/00206819809465201

Aranda-Gómez, J.J., Molina-Garza, R., McDowell, F.W., Vassallo-Morales, L.F., Ortega-Rivera, M.A., Solorio-Munguía, J.G., Aguillón-Robles, A., 2007, The relationships between volcanism and extension in the Mesa Central: The case of Pinos, Zacatecas, Mexico: Revista Mexicana de Ciencias Geológicas, 24, 216-233.

Arehart, G.B., 1996, Characteristics and origin of sediment-hosted disseminated gold deposits: A review: Ore Geology Reviews, 11, 383-403, https://doi. org/10.1016/S0169-1368(96)00010-8
Bai, Y., Yang, T., Liang, J., Qu, J., 2016, The role of biogenic Fe-Mn oxides formed in situ for arsenic oxidation and adsorption in aquatic ecosystems: Water Research, 98, 119-127, https://doi.org/10.1016/j.watres.2016.03.068

Bailey, G.B., 1974, The Occurrence, Origin, and Economic Significance of GoldBearing Jasperoids in the Central Drum Mountains, Utah: Palo Alto, CAL, USA, Stanford University, Ph.D thesis, 300 pp.

Baltuck, M., 1982, Provenance and distribution of tethyan pelagic and hemipelagic siliceous sediments, pindos mountains, Greece: Sedimentary Geology 31, 63-88, https://doi.org/10.1016/0037-0738(82)90008-2

Barboza-Gudiño, J.R., Tristán-González, M., Torres-Hernández, J.R., 1998, The late Triassic-early Jurassic active continental margin of western north America in northeastern Mexico: Geofisica Internacional, 37, 283-292.

Barboza-Gudiño, J.R., Tristán-González, M., Torres-Hernández, J.R., 1999, Tectonic setting of pre-Oxfordian units from central and northeastern Mexico: A review, in Mesozoic Sedimentary and Tectonic History of North-Central Mexico: Geological Society of America, Special Paper 340, 197-210, https://doi.org/10.1130/0-8137-2340-x.197

Barboza-Gudiño, J.R., Orozco-Esquivel, M.T., Gómez-Anguiano, M., ZavalaMonsiváis, A., 2008, The Early Mesozoic volcanic arc of western North America in northeastern Mexico: Journal of South American Earth Sciences 25, 49-63, https://doi.org/10.1016/j.jsames.2007.08.003

Barboza-Gudiño, J. R., Zavala-Monsivais, A., Venegas-Rodriguez, G., BarajasNigoche, L. D., 2010, Late Triassic stratigraphy and facies from northeastern Mexico: Tectonic setting and provenance: Geosphere, 6(5), 621-640

Bau, M., Koschinsky, A., Dulski, P., Hein, J.R., 1996, Comparison of the partitioning behaviours of yttrium, rare earth elements, and titanium between hydrogenetic marine ferromanganese crusts and seawater: Geochimica et Cosmochimica Acta, 60, 1709-1725, https://doi. org/10.1016/0016-7037(96)00063-4

Bau, M., Schmidt, K., Koschinsky, A., Hein, J., Kuhn, T., Usui, A., 2014, Discriminating between different genetic types of marine ferro-manganese crusts and nodules based on rare earth elements and yttrium: Chemical Geology, 381, 1-9, https://doi.org/10.1016/j.chemgeo.2014.05.004

Binns, R.A., 2007, Data report: Petrography and geochemistry of jasperoids from site 1189, ocean drilling program Leg 193: Proceedings of the Ocean Drilling Program: Scientific Results 193, https://doi.org/10.2973/odp. proc.sr.193.211.2006

Bonatti, E., Fisher, D.E., Joensuu, O., Rydell, H.S., Beyth, M., 1972,. Iron-Manganese-Barium Deposit from the Northern Afar Rift (Ethiopia): Economic Geology, 67, 717-730, https://doi.org/10.2113/ gsecongeo.67.6.717

Bonatti, E., Zerbi, M., Kay, R., Rydell, H., 1976, Metalliferous deposits from the Apennine ophiolites: Mesozoic equivalents of modern deposits from oceanic spreading centers: Bulletin of the Geological Society of America, 87, 8394, https://doi.org/10.1130/0016-7606(1976)87<83:MDFTAO >2.0.CO;2

Boström, K., Peterson, M.N.A., 1969, The origin of aluminum-poor ferromanganoan sediments in areas of high heat flow on the East Pacific Rise: Marine Geology, 7, 427-447, https://doi.org/10.1016/0025-3227(69)90016-4

Boström, K., Kraemer, T., Gartner, S., 1973, Provenance and accumulation rates of opaline silica, $\mathrm{Al}, \mathrm{Ti}, \mathrm{Fe}, \mathrm{Mn}, \mathrm{Cu}, \mathrm{Ni}$ and $\mathrm{Co}$ in Pacific pelagic sediments: Chemical Geology, 11, 123-148, https://doi. org/10.1016/0009-2541(73)90049-1

Boynton, W.V., 1984, Cosmochemistry of the Rare Earth Elements: Meteorite Studies: Developments in Geochemistry, 2, 63-114, https://doi.org/10.1016/ B978-0-444-42148-7.50008-3

Brechbühl, Y., Christl, I., Elzinga, E.J., Kretzschmar, R., 2012, Competitive sorption of carbonate and arsenic to hematite: Combined ATR-FTIR and batch experiments: Journal of Colloid and Interface Science, 377, https:// doi.org/10.1016/j.jcis.2012.03.025

Brusnitsyn, A.I., Zhukov, I.G., 2012, Manganese deposits of the Devonian Magnitogorsk palaeovolcanic belt (Southern Urals, Russia): Ore Geology Reviews, 47, 42-58. https://doi.org/10.1016/j.oregeorev.2012.01.003

Brusnitsyn, A.I., Zhukov, I.G., 2018, Geochemistry and formation model of manganiferous rocks in jaspers of the South Urals: Lithology and Mineral Resources, 53, 14-35, https://doi.org/10.1134/S0024490218010030

Camprubí, A., Albinson, T., 2007, Epithermal deposits in México-update of current knowledge, and an empirical reclassification, in Geology of México: Celebrating the Centenary of the Geological Society of México: Geological society of America, Special Paper 422, 377-415, https://doi. 
org/10.1130/2007.2422(14)

Canet, C., Prol-Ledesma, R.M., Torres-Alvarado, I., Gilg, H.A., Villanueva, R.E., Lozano-Santa Cruz, R., 2005, Silica-carbonate stromatolites related to coastal hydrothermal venting in Bahía Concepción, Baja California Sur, Mexico: Sedimentary Geology, 174, 97-113.

Canet, C., Prol-Ledesma, R.M., Bandy, W.L., Schaaf, P., Linares, C., Camprubí, A., Tauler, E., Mortera-Gutiérrez, C., 2008, Mineralogical and geochemical constraints on the origin of ferromanganese crusts from the Rivera Plate (western margin of Mexico): Marine Geology, 251, 47-59, https://doi. org/10.1016/j.margeo.2008.01.012

Carrillo-Bravo, J., 1982, Exploración Petrolera de la Cuenca Mesozoica del Centro de México: Boletín de la Asociación Mexicana de Geólogos Petroleros, 34, 21-46.

Centeno-García, E., Silva-Romo, G., 1997, Petrogenesis and tectonic evolution of Central Mexico during Triassic-Jurassic time: Revista Mexicana de Ciencias Geológicas, 14, 244-260.

Centeno-García, E., Corona-Chávez, P., Talavera-Mendoza, O., Iriondo, A., 2003, Geology and tectonic evolution of the western Guerrero terrane-A transect from Puerto Vallarta to Zihuatanejo, Mexico, in Geologic Transects across Cordilleran Mexico: Guidebook for the Field Trips of the 99th Geological Society of America Cordilleran Section Annual Meeting: Puerto Vallarta, Jal., Mexico, Geological Society of America, 201-228.

Centeno-García, E., Guerrero-Suastegui, M., Talavera-Mendoza, O., 2008, The Guerrero Composite Terrane of western Mexico: Collision and subsequent rifting in a supra-subduction zone, in Special Paper 436: Formation and Applications of the Sedimentary Record in Arc Collision Zones: Geological Society of America, 279-308, https://doi.org/10.1130/2008.2436(13)

Chi Fru, E., Kilias, S., Ivarsson, M., Rattray, J.E., Gkika, K., McDonald, I., He, Q., Broman, C., 2018, Sedimentary mechanisms of a modern banded iron formation on Milos Island, Greece: Solid Earth, 9, 573-598, https://doi. org/10.5194/se-9-573-2018

Choi, J.H., Hariya, Y., 1992, Geochemistry and depositional environment of Mn oxide deposits in the Tokoro Belt, northeastern Hokkaido, Japan: Economic Geology, 87, 1265-1274, https://doi.org/10.2113/gsecongeo.87.5.1265

Conly, A.G., Scott, S.D., Bellon, H., 2011, Metalliferous manganese oxide mineralization associated with the Boléo $\mathrm{Cu}-\mathrm{Co}-\mathrm{Zn}$ district, Mexico: Economic Geology, 106, 1173-1196, https:/doi.org/10.2113/ econgeo.106.7.1173

Crerar, D.A., Namson, J., Chyi, M.S., Williams, L., Feigenson, M.D., 1982, Manganiferous cherts of the Franciscan assemblage; I, General geology, ancient and modern analogues, and implications for hydrothermal convection at oceanic spreading centers: Economic Geology, 77, 519-540, https://doi.org/10.2113/gsecongeo.77.3.519

Cronan, D.S., 1980. Metallogenesis at Oceanic Spreading Centers: Journal of the Geological Society, 137, 369-371, https://doi.org/10.1146/annurev. ea.03.050175.002153

Dasgupta, H.C., Sambasiva Rao, V. V., Krishna, C., 1999, Chemical environments of deposition of ancient iron- and manganese-rich sediments and cherts: Sedimentary Geology, 125, 83-98, https://doi.org/10.1016/ S0037-0738(98)00148-1

Ferrari, L., López-Martínez, M., Rosas-Elguera, J., 2002, Ignimbrite flare-up and deformation in the southern Sierra Madre Occidental, western Mexico: Implications for the late subduction history of the Farallon plate: Tectonics, 21, 17-24, https://doi.org/10.1029/2001tc001302

Ferrari, L., Valencia-Moreno, M., Bryan, S., 2007, Magmatism and tectonics of the Sierra Madre Occidental and its relation with the evolution of the western margin of North America, in Geology of México: Celebrating the Centenary of the Geological Society of México: Geological Society of America, Special Paper 422, 1-39, https://doi.org/10.1130/2007.2422(01)

Flohr, M.J.K., Huebner, J.S., 1992, Mineralogy and geochemistry of two metamorphosed sedimentary manganese deposits, Sierra Nevada, California, USA: Lithos 29, 57-85, https://doi.org/10.1016/0024-4937(92)90034-V

Fournier, R.O., 1985, The Behavior of Silica in Hydrothermal Solutions, in Berger, B.R., Bethke, P.M. (eds.), Geology and Geochemistry of Epithermal Systems: Reviews in Economic Geology, 2, 45-72, https://doi.org/10.5382/ Rev.02.03

Fulignati, P., 2020, Clay minerals in hydrothermal systems: Minerals, 10, 1-17, https://doi.org/10.3390/min10100919

Graney, J.R., Kesler, S.E., Jones, H.D., 1991, Application of gas analysis of jasperoid inclusion fluids to exploration for micron gold deposits: Journal of Geochemical Exploration, 42, 91-106, https://doi. org/10.1016/0375-6742(91)90061-X

Heaney, P.J., 1994, Structure and chemistry of the low-pressure silica polymorphs, in Heaney,P.J., Prewitt, C.T., Gibbs, G.V. (eds) Silica. Physical Behavior, Geochemistry and Materials Applications: Mineralogical Society of America, Reviews in Mineralogy \& Geochemistry, 29, 1-40.

Hedenquist, J., Arribas, A., Gonzalez-Urien, E.G., 2000, Exploration for Epithermal Gold Deposits: Society of Economic Geologists Reviews, 13, 245-277.

Hein, J.R., Koski, R.A., Yeh, H.-W., 1987. Chert-hosted manganese deposits in sedimentary sequences of the Franciscan Complex, Diablo Range, California, in Hein, J.R. (ed.), Siliceous Sedimentary Rocks-Hosted Ores and Petroleum: New York, Hutchinson Ross Publication, 206-230 pp.

Hein, J.R., Koschinsky, A., Halbach, P., Manheim, F.T., Bau, M., Kang, J.-K. Lubick, N., 1997, Iron and manganese oxide mineralization in the Pacific, in Nicholson, K., Hein, J. R., Bfihn, B., Dasgupta, S. (eds.), Manganese Mineralization: Geochemistry and Mineralogy of Terrestrial and Marine Deposits: Geological Society Special Publication, 123-138, https://doi. org/10.1144/GSL.SP.1997.119.01.09

Hein, J.R., Stamatakis, M.G., Dowling, J.S., 2000. Trace metal-rich Quaternary hydrothermal manganese oxide and barite deposit, Milos Island, Greece. Transactions of the Institutions of Mining and Metallurgy: Applied Earth Science, 109, 67-76, https://doi.org/10.1179/aes.2000.109.2.67

Hein, J.R., Koschinsky, A., McIntyre, B.R., 2005, Mercury- and silver-rich ferromanganese oxides, southern California Borderland: Deposit model and environmental implications: Economic Geology, 100, 1151-1168, https://doi.org/10.2113/gsecongeo.100.6.1151

Henry, C.D., Aranda-Gomez, J.J., 1992, The real southern Basin and Range: Mid- to late Cenozoic extension in Mexico: Geology 20, 701-704, https:// doi.org/10.1130/0091-7613(1992)020<0701:TRSBAR > 2.3.CO;2

Hesse, R., 1990, Silica diagenesis: origin of inorganic and replacement cherts: Earth Science Reviews, 26, 253-276.

Hofstra, A.H., Cline, J.S., 2000, Characteristics and Models for Carlin-Type Gold Deposits, in Hagemann, S.G., Brown, P.E. (eds.), Gold in 2000: Society of Economic Geologists Reviews, 163-220, https://doi.org/10.5382/Rev.13.05

Holland, P.T., Beaty, D.W., Snow, G.G., 1988, Comparative Elemental and Oxygen Isotope Geochemistry of Jasperoid in the Northern Great Basin: Evidence for Distinctive Fluid Evolution in Gold-Producing Hydrothermal Systems: Economic Geology, 83, 1401-1423.

Hoppe, M., Barboza-Gudiño, J.R., Schulz, H.M., 2002, Late Triassic submarine fan deposits in northwestern San Luis Potosí, Mexico - Lithology, facies and diagénesis: Neues Jahrbuch Fur Geologie Und Palaontologie - Monatshefte, $12,705-724$.

Huff, Dante E., Holley, E., Guenthner, W.R., Kaempfer, J.M., 2020, Fe-oxides in jasperoids from two gold districts in Nevada: characterization, geochemistry, and (U-Th)/He dating: Geochimica et Cosmochimica Acta, 286, 72-102 https://doi.org/10.1016/j.gca.2020.07.014

Johnston, M.K., Thompson, T.B., Emmons, D.L., Jones, K., 2008, Geology of the cove mine, Lander County, Nevada, and a genetic model for the McCoyCove hydrothermal system: Economic Geology, 103, 759-782, https://doi. org/10.2113/gsecongeo.103.4.759

Jones, D.L., Murchey, B., 1986, Geologic significance of Paleozoic and Mesozoic radiolarian chert: Annual review of Earth and planetary sciences, 14, 455492, https://doi.org/10.1146/annurev.ea.14.050186.002323

Josso, P., Pelleter, E., Pourret, O., Fouquet, Y., Etoubleau, J., Cheron, S., Bollinger, C., 2017, A new discrimination scheme for oceanic ferromanganese deposits using high field strength and rare earth elements: Ore Geology Reviews, 87, 3-15, https://doi.org/10.1016/j.oregeorev.2016.09.003

Juárez-Arriaga, E., Lawton, T.F., Ocampo-Díaz, Y.Z.E., Stockli, D.F., Solari, L., 2019, Sediment provenance, sediment-dispersal systems, and major arcmagmatic events recorded in the Mexican foreland basin, North-Central and Northeastern Mexico: International Geology Review, 61, 2118-2142, https://doi.org/10.1080/00206814.2019.1581848

Jun, P., Haisheng, Y., Wenjie, X., 2010, Geochemical Indication of Sinian Bedded Siliceous Rocks in the Hunan-Guizhou-Guangxi Area and Their Environmental Significance: Acta Geologica Sinica, 74, 46-53, https://doi. org/10.1111/j.1755-6724.2000.tb00430.x

Kirwin, D.J., Royle, D.Z., 2019, Sediment-Hosted Gold Deposits in Southeast 
Asia: Resource Geology, 69, 125-147, https://doi.org/10.1111/rge.12189

Koschinsky, A., Halbach, P., 1995, Sequential leaching of marine ferromanganese precipitates: Genetic implications: Geochimica et Cosmochimica Acta, 59, 5113-5132, https://doi.org/10.1016/0016-7037(95)00358-4

Kuehn, C.A., Rose, A.W., 1992, Geology and Geochemistry of Wall-Rock Alteration at the Carlin Gold Deposit, Nevada: Economic Geology, 87, 1697-1721.

Labarthe-Hernández, G., Aguillón-Robles, A., 1986, Cartografía geológica 1:50,000 hojas: Salinas y Villa de Ramos Edos. de San Luis Potosí y Zacatecas: San Luis Potosí: San Luis Potosí, SLP, Mexico, Universidad Autónoma de San Luis Potosi, Technical Report, 56 pp, https://doi. org/10.13140/rg.2.1.3596.0563

Labarthe-Hernández, G., Tristán-González, M., Aranda-Gómez, J.J., 1982, Revisión estratigráfica del Cenozoico de la parte central del Estado de San Luis Potosí: San Luis Potosí, Mexico, Universidad Autónoma de San Luis Potosí, Technical Report, 80 pp.

Labarthe-Hernández, G., Jimenez-López, L.S., Motilla-Moreno, J.L., 1992, Jasperoide guía posible en la exploración minera Mesa Central, México: Universidad Nacional Autónoma de México, Instituto de Geología, Revista, 10(2), 137-142.

Lovering, T.G., 1962, The origin of jasperoid in limestone: Economic Geology, 57, 861-889, https://doi.org/10.2113/gsecongeo.57.6.861

Lovering, T.G., 1972, Jasperoid in the United States - Its Characteristics, Origin, and Economic Significance: Washington, USA, US Geological Survey, Technical Report, 176 pp.

Lovering, T.G., Heyl, A.V, 1974, Jasperoid as a guide to mineralization in the Taylor Mining District and Vicinity near Ely, Nevada: Economic Geology, 69(1), 46-58, https://doi.org/10.2113/gsecongeo.69.1.46

Madondo, J., Canet, C., González-Partida, E., Rodríguez-Díaz, A.A., NúñezUseche, F., Alfonso, P., Rajabi, A., Pi, T., Blignaut, L., Vafeas, N., 2020, Geochemical constraints on the genesis of the 'Montaña de Manganeso' vein-type Mn deposit, Mexican Plateau: Ore Geology Reviews, 125, 103680 https://doi.org/10.1016/j.oregeorev.2020.103680

Maghfouri, S., Rastad, E., Mousivand, F., Choulet, F., Ye, L., 2017, Geological and geochemical constraints on the Cheshmeh-Frezi volcanogenic stratiform manganese deposit, southwest Sabzevar basin, Iran: Ore Geology Reviews, 89, 96-113. https://doi.org/10.1016/j.oregeorev.2017.06.015

Manning, B.A., Fendorf, S.E., Bostick, B., Suarez, D.L., 2002, Arsenic(III) oxidation and arsenic $(\mathrm{V})$ adsorption reactions on synthetic birnessite: Environmental Science and Technology, 36, 976-981, https://doi. org/10.1021/es0110170

Martini, M., Solari, L., Camprubí, A., 2013, Kinematics of the Guerrero terrane accretion in the Sierra de Guanajuato, central Mexico: New insights for the structural evolution of arc-continent collisional zones: International Geology Review, 55, 574-589, https://doi.org/10.1080/00206814.2012. 729361

McDowell, F.W., Clabaugh, S.E., 1979, Ignimbrites of the Sierra Madre Occidental and their relation to the tectonic history of western Mexico: Geological Society Special Publication, 180, 113-124, https://doi. org/10.1130/SPE180-p113

McKay, W.J., Finlow-Bates, T., 1977, Tridymitic jasperoid deposits in N. W. Queensland: Mineralium Deposita, 12, 96-104, https://doi.org/10.1007/ BF00204508

McKenzie, R.M., 1980, The adsorption of lead and other heavy metals on oxides of manganese and iron: Australian Journal of Soil Research, 18, https:// doi.org/10.1071/SR9800061

McLemore, V.T., Munroe, E.A., Heizler, M.T., McKee, C., 1999, Geochemistry of the Copper Flat porphyry and associated deposits in the Hillsboro mining district, Sierra County, New Mexico, USA: Journal of Geochemical Exploration, 67, 167-189, https://doi.org/10.1016/S0375-6742(99)00072-2

Miura, H., Banerjee, H., Hariya, Y., Dasgupta, S., Roy, S., 1987, Hollandite and cryptomelane in the manganese oxide deposits of the Sausar Group, India: Mineralogical Journal, 13, 424-433, https://doi.org/10.2465/minerj.13.424

Murphy, R.J., 1995, Mapping of jasperoid in the Cedar Mountains, Utah, U.S.A., using imaging spectrometer data: International Journal of Remote Sensing, 16, 1021-1041. https://doi.org/10.1080/01431169508954461

Murray, R.W., 1994, Chemical criteria to identify the depositional environment of chert: general principles and applications: Sedimentary Geology, 90, 213-232, https://doi.org/10.1016/0037-0738(94)90039-6
Nelson, C.E., 1990, Comparative geochemistry of jasperoids from Carlintype gold deposits of the western United States: Journal of Geochemical Exploration, 36, 171-195, https://doi.org/10.1016/0375-6742(90)90055-F

Nicholson, K., 1992, Contrasting mineralogical-geochemical signatures of manganese oxides: guides to metallogenesis: Economic Geology, 87, 1253-1264, https://doi.org/10.2113/gsecongeo.87.5.1253

Nieto-Samaniego, Á.F., Macías-Romo, C., Alaniz-Álvarez, S.A., 1996, Nuevas edades isotópicas de la cubierta volcánica cenozoica de la parte meridional de la Mesa Central, México: Revista Mexicana de Ciencias Geológicas, $13,117-122$.

Nieto-Samaniego, Á.F., Alaniz-Álvarez, S.A., Camprubí, A., 2005, La Mesa Central de México: estratigrafía, estructura y evolución tectónica cenozoica: Boletín de la Sociedad Geológica Mexicana, 57, 285-318, https://doi.org/10.18268/bsgm2005v57n3a3

Nieto-Samaniego, Á.F., Alaniz-Álvarez, S.A., Camprubí, A., 2007, Mesa Central of México: Stratigraphy, structure, and Cenozoic tectonic evolution, in: Special Paper 422: Geology of México: Celebrating the Centenary of the Geological Society of México. Geological Society of America, 41-70, https://doi.org/10.1130/2007.2422(02)

Nieto-Samaniego, A.F., Olmos-Moya, M. de J.P., Levresse, G., Alaniz-Alvarez, S.A., Abdullin, F., del Pilar-Martínez, A., Xu, S., 2019, Thermochronology and exhumation rates of granitic intrusions at Mesa Central, Mexico: International Geology Review, 62, 1-8, https://doi.org/10.1080/002068 14.2019 .1602789

O'Neil, J.R., Bailey, G.B., 1979, Stable isotope investigation of gold-bearing jasperoid in the central Drum Mountains, Utah: Economic Geology, 74, 852-859, https://doi.org/10.2113/gsecongeo.74.4.852

Öksüz, N., Okuyucu, N., 2014, Mineralogy, geochemistry, and origin of Buyukmahal manganese mineralization in the Artova ophiolitic complex, Yozgat, Turkey: Journal of Chemistry, 2014, 1-11. https://doi. org/10.1155/2014/837972

Ouvrard, S., de Donato, P., Simonnot, M.O., Begin, S., Ghanbaja, J., Alnot, M., Duval, Y.B., Lhote, F., Barres, O., Sardin, M., 2005, Natural manganese oxide: Combined analytical approach for solid characterization and arsenic retention: Geochimica et Cosmochimica Acta, 69, 2715-2724, https://doi. org/10.1016/j.gca.2004.12.023

Öztürk, H., Hein, J.R., 1997, Mineralogy and stable isotopes of black shale-hosted manganese ores, Southwestern Taurides, Turkey: Economic Geology, 92, 733-744, https://doi.org/10.2113/gsecongeo.92.6.733

Papavassiliou, K., Voudouris, P., Kanellopoulos, C., Glasby, G., Alfieris, D., Mitsis, I., 2017, New geochemical and mineralogical constraints on the genesis of the Vani hydrothermal manganese deposit at NW Milos island, Greece: Comparison with the Aspro Gialoudi deposit and implications for the formation of the Milos manganese mineralization: Ore Geology Reviews, 80, 594-611, https://doi.org/10.1016/j.oregeorev.2016.07.023

Pokrovski, G.S., Schott, J., Farges, F., Hazemann, J.L., 2003, Iron (III)-silica interactions in aqueous solution: Insights from X-ray absorption fine structure spectroscopy: Geochimica et Cosmochimica Acta, 67, 35593573, https://doi.org/10.1016/S0016-7037(03)00160-1

Ponce S., B.F., Clark, K.F., 1988, The Zacatecas mining district: a tertiary caldera complex associated with precious and base metal mineralization: Economic Geology, 83, 1668-1682. https://doi.org/10.2113/gsecongeo.83.8.1668

Post, J.E., 1999, Manganese oxide minerals: crystal structures and economic and environmental significance, in Proceedings of the 96th National Academy of Sciences Colloquium: Irvine, USA, National Academy of Sciences, 3447-3454, https://doi.org/10.1073/pnas.96.7.3447

Renault, J., Armstrong, A.K., Repetski, J.E., Oscarson, R.L., 1995, Geology, mineralogy, geochemistry, and geothermometry of Kelly Limestone jasperoids, Magdalena mining district, New Mexico: Socorro, New Mexico Bureau of Mines \& Mineral Resources, Technical Report, 51 pp.

Reyes, A.G., 1990, Petrology of Philippine geothermal systems and the application of alteration mineralogy to their assessment: Journal of Volcanology and Geothermal Research, 43, 279-309.

Robertson, A., Degnan, P., 1998, Significance of modern and ancient oceanic Mn-rich hydrothermal sediments exemplified by Jurassic Mn-cherts from Southern Greece: Geological Society Special Publication, 148, 217-240, https://doi.org/10.1144/GSL.SP.1998.148.01.12

Rodríguez-Díaz, A.A., Canet, C., Villanueva-Estrada, R.E., Chacón, E., Gervilla, F., Velasco-Tapia, F., Cruz-Gámez, E.M., González-Partida, E., Casas- 
García, R., Linares-López, C., Pérez-Zárate, C., 2019, Recent Mn-Ag deposits in coastal hydrothermal springs in the Baja California Peninsula, Mexico: Mineralium Deposita, 54, 849-866.

Rodríguez-Ríos, R, Tristán-González, M., Aguillón-Robles, A., 2013, Estructura y geoquímica de un grupo de domos dacíticos del norponiente del campo volcánico de San Luis Potosí, México: Boletín de la Sociedad Geológica Mexicana, 65, 109-122, https://doi.org/10.18268/bsgm2013v65n1a9

Roy, S., 1981, Manganese deposits: London, Academic Press, 451 pp.

Roy, S., 1997, Genetic diversity of manganese deposition in the terrestrial geological record: Geological Society Special Publication, 119, 5-27, https://doi.org/10.1144/GSL.SP.1997.119.01.02

Sánchez-Córdova, M. M., Canet, C., Rodríguez-Díaz, A., González-Partida, E., Linares-López, C., 2020, Water-rock interactions in the Acoculco geothermal system, eastern Mexico: Insights from paragenesis and elemental mass-balance: Chemie Der Erde, 80, 1, https://doi.org/10.1016/j. chemer.2019.06.003

Sánchez-Rojas, L.E., 2013, Jasperoides en el límite de los terrenos Guerrero y Sierra Madre Oriental, in AIMMGM, XXX Convención Internacional de Minería: Acapulco, Gro. Mexico, Asociación de Ingenieros de Minas, Metalurgistas y Geólogos de México, 312-319.

Schwertmann, U., Murad, E., 1983, Effect of $\mathrm{pH}$ on the formation of goethite and hematite from ferrihydrite: Clays \& Clay Minerals, 31, 277-284 https:// doi.org/10.1346/CCMN.1983.0310405

Sinisi, R., Mameli, P., Mongelli, G., Oggiano, G., 2012, Different Mn-ores in a continental arc setting: Geochemical and mineralogical evidences from Tertiary deposits of Sardinia (Italy): Ore Geology Reviews, 47, 110-125, https://doi.org/10.1016/j.oregeorev.2012.03.006

Stenger, D.P., Kesler, S.E., Peltonen, D.R., Tapper, C.J., 1998, Deposition of gold in carlin-type deposits: The role of sulfidation and decarbonation at twin creeks, Nevada: Economic Geology, 93, 201-215, https://doi.org/10.2113/ gsecongeo.93.2.201

Suda, A., Makino, T., 2016, Functional effects of manganese and iron oxides on the dynamics of trace elements in soils with a special focus on arsenic and cadmium: A review: Geoderma, 270, 68-75 https://doi.org/10.1016/j. geoderma.2015.12.017

Sugisaki, R., Yamamoto, K., Adachi, M., 1982, Triassic bedded cherts in central Japan are not pelagic: Nature, 298, 644-647, https://doi. org/10.1038/298644a0

Taylor, P., 1995, Interactions of Silica with Iron Oxides: Effects on Iron oxide Transformation and Sorption Properties: Manitoba, Atomic Energy of Canada, Technical Report, 20 pp.

Taylor, S.R., McLennan, S.M., 1985, The Continental Crust: its Composition and Evolution. An Examination of the Geochemical Record Preserved in Sedimentary Rocks: Oxford, Blackwell Scientific Publications, 312 pp.

Theodore, T.G, Jones, G.M., 1992, Geochemistry and geology of gold in jasperoid, Elephant Head area, Lander County: Nevada, US Geological Survey Bulletin, 62 pp, https://doi.org/10.3133/b2009

Toth, J.R., 1980, Deposition of submarine crusts rich in manganese and iron: Geological Society of America Bulletin, 91, 44-54, https://doi. org/10.1130/0016-7606(1980)91<44:DOSCRI>2.0.CO

Trask, P.D., Rodríguez-Cabo, J.R., 1948, Manganese Deposits of Mexico, in Geologic Investigations in the American Republics, 1946: Washington, USA, United States Geological Survey, Bulletin 954, 209-316, https://doi. org $/ 10.3133 / \mathrm{b} 954 \mathrm{~F}$

Tristán-González, M., 1986, Estratigrafía y tectónica del graben de Villa de Reyes, en los Estados de San Luis Potosí y Guanajuato, México: San Luis Potosí, SLP, Mexico, Universidad Autónoma de San Luis Potosí, Technical Report, 107, 91 pp.

Tristán-González, M., Labarthe-Hernández, G., Aguirre-Díaz, G.J., AguillónRobles, A., 2008, Tectono-volcanic control of fissure type vents for the 28 Ma Panalillo ignimbrite in the Villa de Reyes Graben, San Luis Potosí, México: IOP Conference Series Earth and Environmental Science, 3, 012026. https://doi.org/10.1088/1755-1307/3/1/012026
Tristán-González, M., Aguillón-Robles, A., Barboza-Gudiño, J.R., TorresHernández, J.R., Bellon, H., López-Doncel, R., Rodríguez-Ríos, R., Labarthe-Hernández, G., 2009a, Geocronología y distribución espacial del vulcanismo en el Campo Volcánico de San Luis Potosí: Boletín de la Sociedad Geológica Mexicana, 61, 287-303, https://doi.org/10.18268/ BSGM2009v61n3a1

Tristán-González, M., Aguirre-Díaz, G.J., Labarthe-Hernández, G., TorresHernández, J.R., Bellon, H., 2009b, Post-Laramide and pre-Basin and Range deformation and implications for Paleogene (55-25 Ma) volcanism in central Mexico: A geological basis for a volcano-tectonic stress model: Tectonophysics, 471, 136-152, https://doi.org/10.1016/j.tecto.2008.12.021

Usui, A., Someya, M., 1997, Distribution and composition of marine hydrogenetic and hydrothermal manganese deposits in the northwest Pacific: Geological Society Special Publications, 119, 177-198, https://doi. org/10.1144/gsl.sp.1997.119.01.12

Wilson, I.F., Rocha, V.S., 1948, Manganese deposits of the Montaña de Manganeso mine, San Luis Potosí, Mexico, in Trask, P.D., RodríguezCabo, J.R. (eds.), Manganese Deposits of Mexico: United States Geological Survey, Bulletin,954-F, 267-271

Wilson, A.B., Soulliere, S.J., Skipp, B., Worl, R.G., Rhea, K.P., 1987, Geology and Geochemistry of Jasperoid Near Mackay, Idaho, in Link, P.K., Hackett, W.R., (eds), Guidebook to the Geology of Central and Southern Idaho: CITY, STATE, USA, Idaho Geological Survey Bulletin, 27, 183-192

Wright, J., Schrader, H., Holser, W.T., 1987, Paleoredox variations in ancient oceans recorded by rare earth elements in fossil apatite: Geochimica et Cosmochimica Acta, 51, 631-644, https://doi. org/10.1016/0016-7037(87)90075-5

Yamamoto, S., 1986, Correlation between iron and magnesium and its significance on the distribution of heavy metals in deep-sea cherts: Sedimentary Geology, 49, 261-280, https://doi.org/10.1016/0037-0738(86)90041-2

Yigit, O., Hofstra, A.H., Hitzman, M.W., Nelson, E.P., 2006, Geology and geochemistry of jasperoids from the Gold Bar district, Nevada: Mineralium Deposita, 41, 527-547, https://doi.org/10.1007/s00126-006-0080-8

Ying, S.C., Kocar, B.D., Fendorf, S., 2012, Oxidation and competitive retention of arsenic between iron- and manganese oxides: Geochimica et Cosmochimica Acta, 96, 294-303, https://doi.org/10.1016/j.gca.2012.07.013

Yongzhang, Z., Guangchi, T., Chown, E.H., Guha, J., Huanzhang, L., 1994, Petrologic and geochemical characteristics and origin of Gusui cherts, Guangdong Province, China: Chinese Journal of Geochemistry, 13, 118131. https://doi.org/10.1007/BF02838512

Zamora-Vega, O., Richards, J.P., Spell, T., Dufrane, S.A., Williamson, J., 2018, Multiple mineralization events in the Zacatecas Ag- $\mathrm{Pb}-\mathrm{Zn}-\mathrm{Cu}-\mathrm{Au}$ district, and their relationship to the tectonomagmatic evolution of the Mesa Central, Mexico: Ore Geology Reviews, 102, 519-561. https://doi. org/10.1016/j.oregeorev.2018.09.010

Zhang, G., Liu, F., Liu, H., Qu, J., Liu, R., 2014, Respective role of Fe and Mn oxide contents for arsenic sorption in iron and manganese binary oxide: An X-ray absorption spectroscopy investigation: Environmental Science and Technology, 48, 10316-10322, https://doi.org/10.1021/es501527c

Manuscript received: july 28, 2021

Corrected manuscript received: november 4, 2021

Manuscript accepted: november 6, 2021 